\title{
The effect of atmospheric aerosol particles and clouds on net ecosystem exchange in the Amazon
}

\author{
G. G. Cirino ${ }^{1}$, R. A. F. Souza ${ }^{2}$, D. K. Adams ${ }^{3}$, and P. Artaxo ${ }^{4}$ \\ ${ }^{1}$ National Institute of Research in Amazonia, Rua André Araujo, 2936, Campus II - LBA, 69060-000, Manaus-AM, Brazil \\ ${ }^{2}$ State University of Amazonas, Av. Darcy Vergas, 1200, 69065-020, Manaus-AM, Brazil \\ ${ }^{3}$ Centro de Ciencias de La Atmósfera, Universidad Nacional Autónoma de México, Circuito Exterior s/n, Ciudad \\ Universitaria, Del. Coyoacán, 04510, D.F., Mexico \\ ${ }^{4}$ Institute of Physics, University of São Paulo, Rua do Matão, Travessa R, 187, 05508-090, São Paulo-SP, Brazil \\ Correspondence to: G. G. Cirino (glauber.cirino@inpa.gov.br)
}

Received: 29 August 2013 - Published in Atmos. Chem. Phys. Discuss.: 5 November 2013

Revised: 10 April 2014 - Accepted: 14 May 2014 - Published: 1 July 2014

\begin{abstract}
Carbon cycling in the Amazon is closely linked to atmospheric processes and climate in the region as a consequence of the strong coupling between the atmosphere and biosphere. This work examines the effects of changes in net radiation due to atmospheric aerosol particles and clouds on the net ecosystem exchange (NEE) of $\mathrm{CO}_{2}$ in the Amazon region. Some of the major environmental factors affecting the photosynthetic activity of plants, such as air temperature and relative humidity, were also examined. An algorithm for clear-sky irradiance was developed and used to determine the relative irradiance, $f$, which quantifies the percentage of solar radiation absorbed and scattered due to atmospheric aerosol particles and clouds. Aerosol optical depth (AOD) was calculated from irradiances measured with the MODIS (Moderate Resolution Imaging Spectroradiometer) sensor, onboard the Terra and Aqua satellites, and was validated with ground-based AOD measurements from AERONET (Aerosol Robotic Network) sun photometers. Carbon fluxes were measured using eddy covariance technique at the Large-Scale Biosphere-Atmosphere Experiment in Amazonia (LBA) flux towers. Two sites were studied: the Jaru Biological Reserve (RBJ), located in Rondonia, and the Cuieiras Biological Reserve at the K34 LBA tower (located in a preserved region in the central Amazon). Analysis was performed continuously from 1999 to 2009 at K34 and from 1999 to 2002 at RBJ, and includes wet, dry and transition seasons. In the Jaru Biological Reserve, a $29 \%$ increase in carbon uptake (NEE) was observed when the AOD ranged from 0.10 to 1.5 at $550 \mathrm{~nm}$. In the Cuieiras Biologi-
\end{abstract}

cal Reserve, the aerosol effect on NEE was smaller, accounting for an approximate $20 \%$ increase in NEE. High aerosol loading (AOD above 3 at $550 \mathrm{~nm}$ ) or high cloud cover leads to reductions in solar flux and strong decreases in photosynthesis up to the point where NEE approaches zero. The observed increase in NEE is attributed to an enhancement $(\sim 50 \%)$ in the diffuse fraction of photosynthetic active radiation (PAR). The enhancement in diffuse PAR can be done through increases in aerosols and/or clouds. In the present study, it was not possible to separate these two components. Significant changes in air temperature and relative humidity resulting from changes in solar radiation fluxes under high aerosol loading were also observed at both sites. Considering the long-range transport of aerosols in the Amazon, the observed changes in NEE for these two sites may occur over large areas in the Amazon, significantly altering the carbon balance in the largest rainforest in the world.

\section{Introduction}

Clouds and aerosols influence both the surface energy balance and hydrological cycle through the modification of incoming solar radiation flux and precipitation (Benner and Curry, 1998; Gu et al., 1999, 2001). Consequently, clouds and aerosols exert direct influence on the functioning of terrestrial ecosystems and are, therefore, expected to modify $\mathrm{CO}_{2}$ exchanges in the biosphere-atmosphere interface. The photosynthetic rate of forests tends to increase with 
increases in irradiance (within certain limits) and also is more efficient under conditions of increased diffuse light (Niyogi et al., 2004; Mercado et al., 2009). Photosynthetically active radiation (PAR) flux is also altered with the presence of aerosols and clouds. Over the past 20 years, field observations, over many regions, have shown that the highest rates of carbon uptake in forest ecosystems often occur on slightly cloudy rather than sunny days (Gu et al., 1999; Law et al., 2002; Yamasoe et al., 2006; Oliveira et al., 2007; Jing et al., 2010). Other studies have found that for a given level of irradiance, cloudy days, compared to clear days, generally have higher absolute values of net ecosystem exchange (NEE) (Baldocchi, 1997; Goulden et al., 1997; Gu et al., 1999; Doughty et al., 2010) due to the increase in diffuse radiation, except for highly overcast conditions. Several mechanisms have been proposed to explain these observations including: increases in diffuse radiation (Gu et al., 1999; Yamasoe et al., 2006; Oliveira et al., 2007; Mercado et al., 2009; Jing et al., 2010; Zhang et al., 2010), reduced respiration of sunlit leaves (Baldocchi, 1997; Miller et al., 2004; von Randow et al., 2004), reduction in water vapor pressure deficit (VPD) and, finally, modifications in stomatal dynamics associated with ambient light fluctuations. Although these observations have been limited to flux tower measurements (i.e., a few point measures), it is expected that an increase in carbon uptake under increasing cloudiness and atmospheric aerosol load has implications for the regional and global climate (Abakumova et al., 1996; Gu et al., 1999). This is of particular interest for regions where the percentage of cloud cover and vegetated areas have increased recently (Keeling et al., 1996; Myneni et al., 1997; Gu et al., 1999, 2003).

Long-term studies coordinated by the Large-Scale Biosphere-Atmosphere Experiment in Amazonia (LBA) experiment have shown that the net effect of Amazonian deforestation and reforestation results in an annual net carbon source of $0.15-0.35 \mathrm{Pg} \mathrm{C}$. Adding $\mathrm{C}$ emissions from fire and logging extends the range to an annual net release of $0.2-$ $0.8 \mathrm{Pg} \mathrm{C}$ (Houghton et al., 2009, 2012). On the other hand, studies of forest inventories (Phillips et al., 1998) indicate that intact Amazonian forest may represent a sink of carbon at rates ranging from 0.5 up to a high value of $7 \mathrm{t}$ of $\mathrm{C} \mathrm{ha}^{-1}$ annually (Araújo et al., 2002; Ometto et al., 2005; Malhi, 2010, 2012). Although there is a significant uncertainty regarding the role of the Amazon as a sink or as a source of carbon to the atmosphere (Keller et al., 1996), due to the balance between deforestation and biomass burning emissions versus enhanced carbon uptake, recent studies indicate a near balance in uptake/emissions (Gloor et al., 2013; Gatti et al., 2014). In the Amazon, biomass burning is the main driver of changes in atmospheric composition, accounting for a significant increase in the concentration of gases and particles in the dry season (Artaxo et al., 2002, 2009; Davidson et al., 2012). This translates into a large anthropogenic impact on the local energy balance, and brings important environmental consequences for the entire Amazon ecosystem (Ar- taxo et al., 1998; Schafer et al., 2002; Procopio et al., 2004; Sena et al., 2013). In the dry season, where biomass burning emissions are widespread, the reduction in the ground-based flux of PAR can reach values on the order of $70 \%$ (Eck et al., 2003; Procopio et al., 2004), strongly impacting Amazon rainforest primary production (Artaxo et al., 2013). This augmented aerosol loading boosts the fraction of diffuse radiation in the atmosphere, which, in turn, increases the penetration of solar radiation into the forest canopy. The vegetation uses diffuse radiation more efficiently for photosynthesis, which increases forest carbon uptake; a fact that partly balances the effects of reducing direct radiation flux. Most of the Amazon, even outside the region of the so-called "arc of deforestation" experiences the effects of biomass burning emissions to some extent, with the resulting modification in ecosystem functioning (Oliveira et al., 2007; Doughty et al., 2010; Artaxo et al., 2013).

Atmospheric aerosol lifetime is on the order of days to weeks, and thus long-range transport of aerosol particles implies that biomass burning may impact the radiation budget of areas thousands of kilometers away (Seinfeld and Pandis, 2006). More knowledge is needed with respect to the impacts that clouds and aerosols have on carbon absorbed by the Amazon forest annually, especially in regions of the central Amazon, which have smaller impacts from biomass burning emissions compared to the southern Amazon. Longterm $\mathrm{CO}_{2}$ flux monitoring has been limited to seven flux towers distributed over 5.5 million $\mathrm{km}^{2}$ and operated by the LBA experiment (da Rocha et al., 2009). Besides the nearly 10 years of measurement records, only a few studies analyzed the impact of clouds and aerosols on the carbon cycle in the Amazon. Moreover, the limited number of sun photometers for continuous monitoring of aerosol optical depth at these flux tower sites, especially in the central Amazon, has greatly hampered a broader and more precise mapping of the relationship between biomass burning aerosols and the net balance of carbon in the Amazonian forest. A few previous studies have shown a significant relationship between fluxes and aerosols in Amazon, but these were made from relatively short data time series and are representative of only two regions of the Amazon: wet and seasonally dry forest (Yamasoe et al., 2006; Oliveira et al., 2007; Doughty et al., 2010). This study performed an analysis over the longest possible data set in the Amazon, and included analysis in the central Amazon that has a shorter dry season compared to other sites such as Santarem. In the present study we focused on the influence of clouds and aerosol particles on the NEE for two different sites in the Amazon. Furthermore, the net effect of the increase in diffuse radiation fraction and the reduction of the total solar flux on carbon fluxes was analyzed. This analysis was carried out using long-term LBA meteorological and eddy covariance flux data, in addition to aerosol optical depth (AOD) measurements from MODIS (Moderate Resolution Imaging Spectroradiometer). Other possible environmental 
variables that can affect NEE in tropical forests were also analyzed.

\section{Data and measurement}

\subsection{Site descriptions}

\subsubsection{Jaru Biological Reserve (RBJ)}

The Jaru Biological Reserve $\left(10^{\circ} 05^{\prime} 00^{\prime \prime} \mathrm{S}\right.$ and $\left.61^{\circ} 55^{\prime} 00^{\prime \prime} \mathrm{W}\right)$ is densely forested and located approximately $100 \mathrm{~km}$ north of the urban area of Ji-Parana, Rondonia, Brazil. It consists of approximately 268000 ha of primary forest at an altitude ranging between 100 and $150 \mathrm{~m}$ above sea level with typical canopy height of 30-35 m. The Jaru Biological Reserve $(\mathrm{RBJ})$ is a protected area located in southeastern Rondonia and is strongly affected every year by biomass burning emissions (Andreae et al., 2004; Oliveira et al., 2007; Silva Dias et al., 2002). Previous studies have shown strong seasonality and carbon assimilation, around 18 and $8 \mathrm{~kg} \mathrm{C} \mathrm{ha}^{-1}$ day $^{-1}$ during on the wet and dry season, respectively (von Randow et al., 2004). At this site, this study analyzed approximately 4 years of measurements of carbon flux and associated variables (March 1999 to November 2002). The different geological substrates and diverse rainfall patterns at this site promote numerous vegetation types and five phytoecological formations, namely: Open Tropical Rainforest, Rainforest, Vegetation Transition or Contact, Cerrado and Alluvial Pioneer Formations. Average annual rainfall ranges from 1400 to $2600 \mathrm{~mm} \mathrm{yr}^{-1}$ with the dry season (rainfall $<60 \mathrm{~mm}$ per month) extending from June to September (Machado et al., 2004; da Rocha et al., 2009). The average annual air temperature is about $24-26^{\circ} \mathrm{C}$, with average relative humidity being around $90 \%$, although dropping to around $40 \%$ in August. During the dry season, weak cold fronts locally called "friagens" can also lower temperatures substantially $\left(\sim 15^{\circ} \mathrm{C}\right)$ (Fisch et al., 1998).

\subsubsection{Cuieiras Biological Reserve (K34)}

The second sampling site used in this study is the K34 LBA tower flux located in the central Amazon $60 \mathrm{~km}$ northwest of Manaus. The site was chosen as representative of an intact, well-preserved forest site with little disturbance or deforestation in recent decades. In the Cuieiras Biological Reserve $\left(2^{\circ} 36^{\prime} 32.67^{\prime \prime} \mathrm{S}, 60^{\circ} 12^{\prime} 33.48^{\prime \prime} \mathrm{W}\right)$, the seasonal variations in net carbon uptake by the ecosystem are small (Araújo et al., 2002; de Araújo et al., 2010). At this site, this work has analyzed a long time series ( $\sim 10$ years) of carbon flux and meteorological variables, between June 1999 and December 2009. The K34 tower has been widely utilized for over 10 years for a range of meteorological studies, including energy and trace gases fluxes (Araujo et al., 2002; de Araujo et al., 2010) and also tropospheric variables such as precipitable water vapor (Adams et al., 2011). The study area is

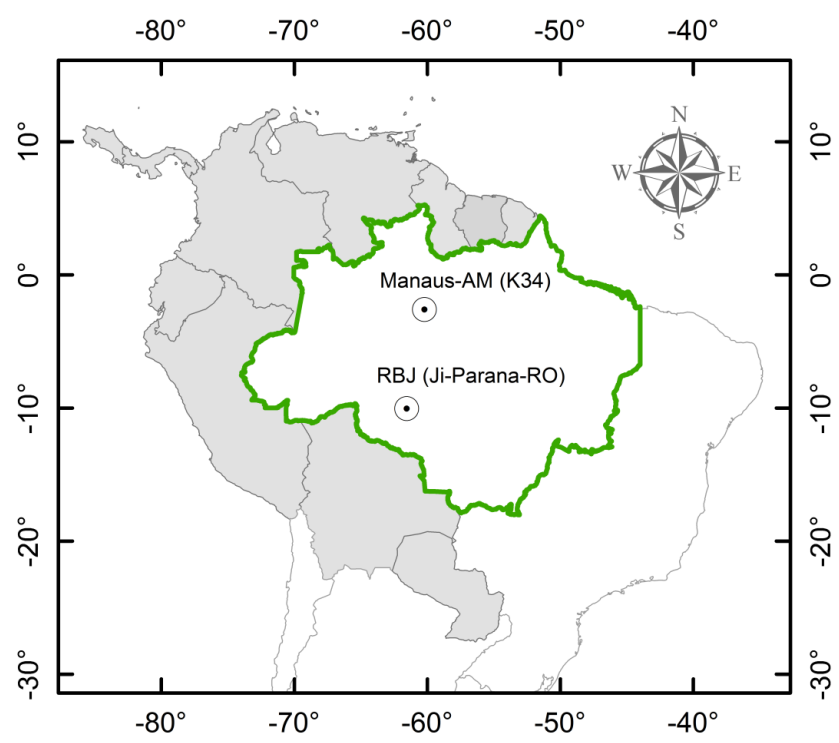

Figure 1. Map of the study sites: Jaru Biological Reserve (RBJ), close to the city of Ji-Parana, Rondonia, Brazil and Cuieiras Biological Reserve (ZF-2, also called LBA tower K34), in Manaus, Amazonas, Brazil.

densely forested with typical canopy height of $30 \mathrm{~m}$ with significant variation $(20-45 \mathrm{~m})$ throughout the reserve. The topography is complex, containing a sequence of plateaus, hills and lowlands. The topography of this site, which has a maximum altitude of $120 \mathrm{~m}$, is $31 \%$ plateau, $26 \%$ slope and $43 \%$ valley (Rennó et al., 2008). More detailed characteristics of the soil in this region can be found in Ferraz et al. (1998); Higuchi et al. (1998) and Oliveira and Amaral (2005). The climate is characterized by an average annual temperature of $26.0^{\circ} \mathrm{C}$, with minimum and maximum values of $23.5^{\circ} \mathrm{C}$ and $31.0^{\circ} \mathrm{C}$, respectively, and an average annual relative humidity of $84 \%$. The average annual precipitation is approximately $2300 \mathrm{~mm}$. The annual cycle of precipitation is characterized by a wet season from January to April and a dry season from July to September. The dry season (rainfall less than $100 \mathrm{~mm}$ ) also vary from year-to-year in length and intensity (da Rocha et al., 2009). Figure 1 shows the locations of the two sites used in this study.

\subsection{Measurements}

\subsubsection{Meteorological and $\mathrm{CO}_{2}$ flux measurements}

The two LBA flux tower sites chosen for this study have made long-term measurements of carbon flux, radiation and vertical profiles of $\mathrm{CO}_{2}$, temperature and relative humidity within the canopy. Separated by approximately $1000 \mathrm{~km}$, each site experiences a different precipitation regime and nearby land-use activities. In this study, a long time series of $\mathrm{CO}_{2}$ flux measurements and meteorological variables are used. Our database includes measurement of the net 
Table 1. List of measurements, instruments and measurement heights for the automatic weather station and eddy correlation instrumentation installed on the K34 /Manaus-AM and RBJ/Ji-Paraná LBA towers.

\begin{tabular}{|c|c|c|c|c|}
\hline \multicolumn{5}{|c|}{ Set list instruments and measurements } \\
\hline \multirow[t]{2}{*}{ Measurements } & \multirow[t]{2}{*}{ Instruments } & \multirow[t]{2}{*}{ Unit } & \multicolumn{2}{|c|}{ Measurement heights [m] } \\
\hline & & & K34 & RBJ \\
\hline Net radiation & NR-LITE (Kipp \& Zonen) & $\mathrm{W} \mathrm{m}^{-2}$ & 44.0 & - \\
\hline $\begin{array}{l}\text { Incident and reflected } \\
\text { shortwave radiation }\end{array}$ & $\begin{array}{l}\text { CM21 pyranometers (Kipp } \\
\& \\
\text { Zonen) }\end{array}$ & $\mathrm{W} \mathrm{m} \mathrm{m}^{-2}$ & 44.6 & 54.3 \\
\hline $\begin{array}{l}\text { Incident and emitted } \\
\text { long wave radiation }\end{array}$ & $\begin{array}{l}\text { CG1 pyrgeometers (Kipp \& } \\
\text { Zonen) }\end{array}$ & $\mathrm{W} \mathrm{m}^{-2}$ & 44.6 & 54.3 \\
\hline $\begin{array}{l}\text { Photosynthetically active } \\
\text { radiation (PAR) }\end{array}$ & $\begin{array}{l}\text { LI-COR LI-190SZ } \\
\text { quantum sensor }\end{array}$ & $\mu \mathrm{mol} \mathrm{m}{ }^{-2} \mathrm{~s}^{-1}$ & 51.6 & 60.6 \\
\hline $\begin{array}{l}\text { Vertical profile of air } \\
\text { temperature }\end{array}$ & PT100 resistors on HMP35A & ${ }^{\circ} \mathrm{C}$ & $\begin{array}{l}51.1,42.5,35.5 \\
28.0,15.6,5.2\end{array}$ & $\begin{array}{l}\text { 60.0, 45.2, } 35.0, \\
25.3,15.3,5.3\end{array}$ \\
\hline $\begin{array}{l}\text { Vertical profile of }\left[\mathrm{CO}_{2}\right] \\
\text { and water vapor }\left[\mathrm{H}_{2} \mathrm{O}\right]\end{array}$ & $\begin{array}{l}\text { CIRAS-SC IRGA (PP Sys- } \\
\text { tems) }\end{array}$ & ppm & $\begin{array}{l}51.1,42.5,35.5 \\
28.0,15.6,5.2,0.5\end{array}$ & $\begin{array}{l}62.7, \quad 45.0, \quad 35.0, \\
25.0,2.7,0.05\end{array}$ \\
\hline Relative humidity & $\begin{array}{l}\text { HMP35A and HMP45AC } \\
\text { thermohygrometer (Vaisala) }\end{array}$ & $\%$ & 51.1 & 60.0 \\
\hline Rainfall & ARG-100 rain gauge (EML) & $\mathrm{mm}$ & 51.3 & 60.3 \\
\hline Atmospheric pressure & $\begin{array}{l}\text { PTB100A barometer } \\
\text { (Vaisala) }\end{array}$ & $\mathrm{hPa}(\mathrm{mb})$ & 32.0 & 40.0 \\
\hline $\begin{array}{l}\text { High-frequency measure- } \\
\text { ments } \\
\text { of } 3-\mathrm{D} \text { wind speed, tempera- } \\
\text { ture, } \mathrm{H}_{2} \mathrm{O} \text { and } \mathrm{CO}_{2} \text { concen- } \\
\text { tration } \\
(10.4 \mathrm{~Hz})\end{array}$ & $\begin{array}{l}\text { Eddy correlation system } \\
\text { (Gill Sonic Anemometer and } \\
\text { LI-COR } 6262 \text { IRGA) }\end{array}$ & $\mathrm{ms}^{-1}$ & 53.1 and 46.1 & 62.7 \\
\hline
\end{tabular}

Height of the canopy top at both sites $(\sim 35 \mathrm{~m})$.

eddy covariance flux of $\mathrm{CO}_{2}$ (NEE), and micrometeorological measurements, derived from automatic weather stations (AWS) distributed vertically along the tower. Micrometeorological measurements and carbon fluxes were recorded by data loggers at different time steps and were averaged for every 30 to $60 \mathrm{~min}$. AWS stations measured solar radiation flux $(0.3-3 \mu \mathrm{m})$, thermal radiation $(4.5-42 \mu \mathrm{m})$ and reflected radiation (all to within $\pm 1 \%$ ). Basic meteorological parameters (temperature, humidity and rain amount) were also measured. The vertical profile of $\mathrm{CO}_{2}$ concentrations between the soil and the top of the canopy were measured using a closed path infrared gas analyzer. The fluxes of $\mathrm{H}_{2} \mathrm{O}$ and $\mathrm{CO}_{2}$ were performed through the eddy covariance system similar to that described by Moncrieff et al. (1997). The system is comprised of a sonic anemometer, and an infrared gas analyzer. Fluxes, means and variances were averaged every $30 \mathrm{~min}$, with data processed using Alteddy software (version 3.1) based on Aubinet et al. (2000). Table 1 contains a detailed list of the parameters measured at both sites. The data collection heights as well as canopy heights for both sites can be seen in Table 1.

\subsubsection{Measurements of aerosol optical depth}

Remotely sensed aerosol optical depth measurements at $550 \mathrm{~nm}$ are taken from two sources, the MODIS instrument on the Aqua and Terra platforms (MODIS Atmospheric Products, MOD/MYD-04L2) and from the solar radiometer network AERONET (Aerosol Robotic Network) (Holben et al., 1998). The Cimel CE 318-A radiometers have detectors capable of performing direct solar radiation as well as almucantar measurements. Direct solar measurements have a field of view of $1.2^{\circ}$ for eight spectral bands centered at $340,380,440,500,670,870,940$ and $1020 \mathrm{~nm}$, determined by rotational interference filters located within the sensor. Each measurement takes approximately $10 \mathrm{~s}$. In this study, the AERONET measurements were considered the standard measurement of AOD and used only to validate the MODIS retrieved AOD. MODIS AOD was calculated from February 2000 to September 2010 (at the RBJ site) and February 2000 to November 2002 (at the K34 site). In order to minimize cloud contamination issues, only AERONET level 2.0 AOD data were used in the comparison with MODIS AOD. The remotely sensed estimations of AOD are typically made daily between 09:30 and 11:55 LT (local time) in the case of 
MODIS-Terra, and between 12:40 and 14:55 LT in the case of MODIS-Aqua. For consistent comparisons between the estimates of AOD (MODIS) and AERONET, only the radiation flux between solar zenithal angles from 10 to $55^{\circ}$ were considered. The number of days with AOD data was maximized by combining the estimates from both the Terra and Aqua satellites. These estimates are averages of an area of $50 \times 50 \mathrm{~km}$ collocated with the LBA flux towers. Periods when either measurements of $\mathrm{CO}_{2}$ or MODIS AOD were absent were not employed in this study.

\subsection{Methods}

In this section, a description of the procedures employed to observe aerosol and cloud effects on net radiation fluxes is provided. Firstly, the variables used to estimate the cloudiness are presented. In meteorological observations, the cloudiness is usually measured in tenths or eighths of sky covered. However, in the present study, the word "cloud" will be used to refer to the presence, quality or quantity of clouds in the sky. A method for identifying clear-sky conditions was also developed. The procedures used to evaluate cloud/aerosol influence on NEE including the environmental factors that possibly contribute to changes in the carbon flux are also described.

\subsubsection{Calculation of net ecosystem $\mathrm{CO}_{2}$ exchange}

At both sites, NEE is obtained from turbulent flux measurements by means of the eddy covariance technique taking into account the storage term (de Araújo et al., 2010; von Randow et al., 2004). Micrometeorological sensors distributed vertically along the tower are essential for the NEE calculations (Richardson and Hollinger, 2005), using continuous measurements of the $\mathrm{CO}_{2}$ profile between soil and top of the tower. Under these conditions, NEE can be approximated by

$\mathrm{NEE} \approx F_{\mathrm{c}}+\mathrm{Stg}$

where $F_{\mathrm{c}}$ is called " $\mathrm{CO}_{2}$ turbulent flux", calculated by the eddy covariance system above the treetops; Stg (the storage term) is the $\mathrm{CO}_{2}$ concentration (non-turbulent term), measured in a vertical profile at discrete levels $z_{i}$ of $\Delta z_{i}$ thickness, from close to the soil surface to the point of eddy covariance measurements around $51 \mathrm{~m}$ and $63 \mathrm{~m}$ on the $\mathrm{K} 34$ and RBJ towers, respectively (Finnigan, 2006; Loescher et al., 2006; Dolman et al., 2008). At RBJ, procedures for calculating the NEE were made following von Randow et al. (2004). At K34, vertical profiles of $\mathrm{CO}_{2}$ concentrations were calculated following Aubinet et al. (2001) and de Araujo et al. (2010).

$\mathrm{Stg}=P_{\mathrm{a}} / R T_{\mathrm{a}} \sum_{0}^{z}(\Delta C / \Delta t) \Delta z$,

where $P_{\mathrm{a}}$ is the atmospheric pressure $\left(\mathrm{N} \mathrm{m}^{-2}\right), R$ is the molar gas constant $\left(\mathrm{Nm} \mathrm{mol}^{-1} \mathrm{~K}^{-1}\right), T_{\mathrm{a}}$ is the air temperature $(\mathrm{K})$,
$C$ is the $\mathrm{CO}_{2}$ concentration $\left(\mu \mathrm{mol} \mathrm{mol}{ }^{-1}\right), t$ is the time (s) and $z$ is the maximum height $(\mathrm{m})$ between the ground and the canopy (Finnigan, 2006; Loescher et al., 2006).

\subsubsection{Procedure for the quantification of aerosol and cloud effects on NEE}

Since no direct observations of cloud cover were made at $\mathrm{K} 34$ or RBJ, measurements of global solar radiation at the surface to assess the presence or absence of clouds were used (Gu et al., 1999; Oliveira et al., 2007; Zhang et al., 2010; Bai et al., 2012). The critical step in this approach is identifying what is a "clear-sky" day in order to establish a basis for comparison with cloudy or partly cloudy days. In the present study, the words "cloud" or "cloudiness" were used to refer to the presence, without regard for quality or quantity, of clouds in the sky (Gu et al., 1999). The concept of relative irradiance, $f$, was used to determine the reduction of incident solar irradiance due to clouds and/or aerosols and associate this with the changes in NEE, which also changes with temperature and relative humidity variations. In this study, the quantity $f$ was calculated following Oliveira et al. (2007):

$f=\frac{S\{\mathrm{AOD}, \text { cloudiness }\}}{S_{0}\left\{\mathrm{AOD}_{0.10}, \text { cloudless }\right\}} \times 100$,

where $S\left(\mathrm{~W} \mathrm{~m}^{-2}\right)$ is the total incident solar radiation measured at the surface for a given time (with or without the presence of aerosols and clouds) and $S_{0}\left(\mathrm{~W} \mathrm{~m}^{-2}\right)$ is the expected total incident solar irradiance at the surface in a cloudless atmosphere with an aerosol optical depth of 0.10 at $550 \mathrm{~nm}$ (Holben et al., 1996; Guyon et al., 2003). Previous studies in the Amazon have shown that the background AOD, due to atmospheric natural conditions, is about 0.1 at $550 \mathrm{~nm}$. There are few models assessed in the literature for the calculation of $S_{0}$ (Ricchiazzi et al., 1998; Duchon and O'Malley, 1999). In this study, we chose to employ an algorithm for clear-sky irradiance that would include the intrinsic characteristics of local conditions in the Amazon. $S_{0}$ and $f$ were calculated employing the methodology of $\mathrm{Gu}$ et al. (1999), which establishes a set of criteria to find clear-sky days. These criteria are based on the concept of clearness index, $k t$, which is discussed in detail in the next section. In this study, $k t$ was used to find $S_{0}$ and thus determine $f$. To observe only the aerosol effects on the solar irradiance flux (computed from $f$ ), and consequently on the NEE measurements, the aerosol effects have to be isolated from the cloud effects. Radiation measurements were classified as affected only by aerosols if they were performed under cloudless conditions, that is, under clear-sky conditions (Oliveira et al., 2007). The MODIS sensor has an algorithm to exclude cloud contamination of the AOD measurements (King et al., 1999; 2003; Remer et al., 2005). 


\subsubsection{The definition of the clearness index}

The relative irradiance, $f$, provides an estimation of changes in cloudiness and AOD as a result of changes in measured solar radiation fluxes. However, the concept requires that $S_{0}$ be available. When clear-sky irradiance is not available, sky conditions can be described in terms of the "clearness index", $k t$, defined as the ratio of solar radiation received at the surface to the solar irradiance at the top of the atmosphere (TOA). For a given solar elevation angle, small $k t$ values indicate an increase in the cloud coverage and/or aerosol loading, while higher values indicate more clear-sky conditions (Gu et al., 1999; Zhang et al., 2010; Bai et al., 2012). Mathematically, the clearness index can be expressed by

$$
\begin{aligned}
k t & =S / S_{\mathrm{e}} \\
, S_{\mathrm{e}} & =S_{\mathrm{sc}}[1+0.033 \cos (360 t d / 365)] \sin \beta,
\end{aligned}
$$

where $S$ is the ground-based total solar irradiance actually measured at the surface, while $S_{e}$ is the TOA solar irradiance, where $S_{\mathrm{sc}}\left(\sim 1367 \mathrm{~W} \mathrm{~m}^{-2}\right)$ is the solar constant, and $t d$ the Julian day. For the calculation of $\sin \beta$ the following equation is used:

$\sin \beta=\sin \varphi \cdot \sin \delta+\cos \varphi \cdot \cos \delta \cdot \cos \omega$,

where $(\beta)$ is the solar elevation angle and $(\varphi),(\delta)$ and $(\omega)$ are, respectively, the latitude, the declination of the Sun (in degrees) and the hour angle. An interesting characteristic of this definition is that it is possible to establish a clearness index for clear skies (i.e., cloud free and AOD 0.10). Under these conditions, it is possible to denominate a clear-sky clearness index, $k t^{*}$, and Eq. (4a) can be rewritten as:

$k t^{*}=\frac{S_{0}}{S_{\mathrm{e}}}$.

Therefore, the ratio between $k t$ and $k t^{*}$ provides the relative irradiance $f$; see Eq. (3). The physical concepts of $k t$ and $k t^{*}$ indicate an alternate way to determine $f$ to a good approximation.

\subsubsection{Defining clear skies conditions}

To quantify the specific influence of clouds on NEE, firstly, the NEE behavior on days with minimal cloud cover was determined using the method of separation of clear days from $\mathrm{Gu}$ et al. (1999). This provides a basis for the comparison of NEE behavior for "clear-sky days" vs. aerosol and/or cloudy days. The clear-sky days were defined based on a $4 \mathrm{~h}$ period, evaluated for two temporal intervals: between 08:00 and 12:00 and from 12:00 to 16:00 LT (averages were made of the irradiances over each $4 \mathrm{~h}$ period). These periods were used because of the timing of the close overpass of the Aqua and Terra satellites over the Amazon. To ascertain the accuracy of our cloudiness estimates with an independent data set, time-averaged GOES10 channel 4 brightness temperature was used over the same two $4 \mathrm{~h}$ periods for the pixel $(4 \times 4 \mathrm{~km})$ containing the K34 and RBJ sites. Brightness temperatures less than $280 \mathrm{~K}$ were assumed to result from cloudiness for that particular pixel. The clear days selected by the method of Gu (1999) were compared with the clear-sky days from satellite observations (GOES10) and it was found that about $70 \%$ of the number of clear days selected by GOES10 were also selected by the method of Gu (1999).

Two patterns for clear mornings and afternoons were assumed (Gu et al., 1999; Zhang et al., 2010; Bai et al., 2012): (1) $k t$ should increase smoothly with the solar zenith angle, $\cos (z)$, and (2) the relationship between clear-sky $k t$ and $\cos (z)$ must form an envelope in the lumped scatterplot of $k t$ against $\cos (z)$. The following steps and procedures were employed to find $k t^{*}$ : First, values of $k t$ were plotted against time during the day. Only the mornings and afternoons that showed small variations in $k t$ were selected. The solar zenith angle $\cos (z)$ from the clear-sky days were plotted on the same graph. The $k t$ values which were outside the two patterns set out above were excluded from our database. Finally, the values of $k t$ selected during mornings or afternoons were plotted against the solar zenith angle again to check if the clear-sky days selected met the two criteria set out above.

The degree of dependence between $k t^{*}$ (clear-sky clearness index) and $\cos (z)$ was used to assess whether the mornings and clear afternoons were accurately selected. This relationship can be expressed as follows:

$k t_{0}=a_{1} \cos ^{3}(z)+a_{2} \cos ^{2}(z)+a_{3} \cos (z)+a_{4}$,

where $k t_{0}$ is the clear-sky clearness index from the regression curves (Fig. 2a and b); $z$ is the calculate solar zenith angle (Gates, 1980); $a_{1}, a_{2}, a_{3}$ and $a_{4}$ are the regression coefficients specific to the selected clear mornings and afternoons, calibrated to local conditions of the tropical forest at K34 and RBJ, respectively. The clear-sky irradiance $\left(S_{0}^{\prime}\right)$ was also determined, and obtained similarly to Eq. (7). The coefficients $k t_{0}$ and $S_{0}^{\prime}$ are fixed as shown in Table 2. Figure 2 shows asymmetries between the period of morning and afternoon light at both sites. The values of $k t^{*}$ selected during afternoons are slightly higher when compared with the indexes of selected mornings, especially for low angles (less than $\cos ^{-1}$ 0.45). Similar results were obtained by $\mathrm{Gu}$ et al. (1999) and Zhang et al. (2010). For a given solar zenith angle, decreases in the clearness index generally indicate an increase in the depth of the clouds, with the exception for situations in which the clouds are not distributed uniformly across the sky; i.e., when there is a cloud gap effect (Gu et al., 1999; Oliveira et al., 2007).

\subsubsection{Determination of NEE on clear-sky days}

In this study, the influence of aerosols and clouds on carbon uptake is analyzed mainly in terms of variations in NEE and environmental factors through their impact on $f$. The 
Table 2. Regression coefficients of relationships between clear-sky irradiance $\left(S_{0}\right)$ and solar zenithal angles cos $(z)$ as well as relationships between clear-sky clearness index $\left(k t^{*}\right)$ and solar zenithal angles $\cos (z)$ of Eq. (7) for the morning and afternoon periods of the K34 and RBJ sites. Periods of measurements: K34: 2000-2009 and RBJ: 2000-2002.

\begin{tabular}{|c|c|c|c|c|}
\hline \multirow{2}{*}{ Regression coef. } & \multicolumn{2}{|c|}{ Trop. rainforest Manaus (K34) } & \multicolumn{2}{|c|}{ Trop. rainforest Ji-Parana (RBJ) } \\
\hline & Morning & Afternoon & Morning & Afternoon \\
\hline \multicolumn{5}{|c|}{ Clear-sky irradiance $\left[S_{0}\right]$} \\
\hline \multicolumn{5}{|c|}{$\left[S_{0}^{\prime}=p_{1} \cos ^{3}(z)+p_{2} \cos ^{2}(z)+p_{3} \cos (z)+p_{4}\right]$} \\
\hline$p_{1}$ & -1026 & -685 & -813 & -644 \\
\hline$p_{2}$ & 2027 & 1210 & 1867 & 1188 \\
\hline$p_{3}$ & -110 & 240 & -170 & 295 \\
\hline$p_{4}$ & 10 & 14 & 11 & 18 \\
\hline$R$-squared & 0.95 & 0.85 & 0.95 & 0.92 \\
\hline \multicolumn{5}{|c|}{ Clear-sky clearness index $\left[k t^{*}\right]$} \\
\hline \multicolumn{5}{|c|}{$\left[k t_{0}=a_{1} \cos ^{3}(z)+a_{2} \cos ^{2}(z)+a_{3} \cos (z)+a_{4}\right]$} \\
\hline$a_{1}$ & -0.01 & -0.31 & -0.14 & -0.54 \\
\hline$a_{2}$ & -0.69 & 0.16 & -0.29 & 0.63 \\
\hline$a_{3}$ & 1.39 & 0.41 & 1.13 & 0.13 \\
\hline$a_{4}$ & -0.02 & 0.31 & -0.04 & 0.41 \\
\hline$R$-squared & 0.85 & 0.30 & 0.87 & 0.41 \\
\hline
\end{tabular}

observed NEE on clear days (AOD $<0.1$ and cloud free) was used also as a basis of comparison for cloudy days and/or days with high aerosol loading. The changes in the observed NEE relative to NEE with clear skies were used to determine the percentage effect of aerosols and clouds on the NEE ( $\%$ NEE). The \%NEE was calculated by the following relationship (Bai et al., 2012; Gu et al., 1999; Oliveira et al., 2007):

$\% \mathrm{NEE}=\left(\frac{\operatorname{NEE}(z)-\operatorname{NEE}(z)_{\text {csky }}}{\operatorname{NEE}(z)_{\text {csky }}}\right) \times 100$,

Where $\operatorname{NEE}(z)$ is a measure of NEE under a given sky condition throughout the day and $\mathrm{NEE}_{\text {csky }}$ is the NEE calculated under sky conditions with low aerosol loading in the atmosphere and minimal cloud cover $(f \approx 1.0$, AOD $\sim 0.10)$.

In order to largely eliminate the interference of solar elevation angle on the analysis of changes in NEE or \% NEE versus $k t$ or $f$, we grouped the data into intervals of solar elevation angles of approximately $15^{\circ}$. This interval was small enough to minimize solar elevation effects during the day and to represent changes in NEE with $k t$ or $f$ only in response to changes in the ecosystem resulting from aerosols and/or clouds. Moreover, this interval provides sufficient sample size for statistical analyses. Zenith angles of $5^{\circ}$ intervals proved too small to develop a robust statistical analysis (Gu et al., 1999). Values above $50^{\circ}$ or around $0^{\circ}$ (solar angles very near the horizontal and vertical plane, respectively) were, in general, too heavily contaminated by clouds. Therefore, an elevation angle ranging from 10 to $35^{\circ}$ was chosen to be optimal for measuring the ecosystem response to changes in cloudiness and AOD rather than the effect of variations in solar zenith angles.

The results in Fig. 3a and $b$ show the solar zenith angle interval for which carbon fluxes experience the greatest variation. The fitted equation was $\mathrm{NEE}=n_{3}+n_{2}(\mathrm{SZA})+$ $n_{1}(\mathrm{SZA})^{2}$. The obtained coefficients of NEE (clear-sky) are listed in Table 3. The statistical parameters $R^{2}$ and $p$ value (Fig. 3a and b) were statistically significant considering the measurement sample size. The sampling size for K34 is larger than 59000 points, and larger than 26000 for RBJ. The $R^{2}$ is statistically significant at the $95 \%$ confidence level, indicating a high degree of relationship between the NEE and solar zenithal angle. These coefficients are statistically consistent with those reported by Oliveira et al. (2007) for RBJ, although performed with different methodologies for calculating clear-sky conditions, but are quite different from those obtained in other ecosystems, such as temperate deciduous forests, mixed forests and pine forests, found in southern Canada and northwest China (Gu et al., 1999; Zhang et al., 2010).

\subsubsection{Methods to derive total and diffuse PAR}

Unfortunately, measurements of diffuse PAR were not available at either K34 or RBJ. Therefore, to determine the diffuse component of total PAR, we followed the methods derived by Spitters et al. (1986) and Reindl et al. (1990) which have been widely used in the literature (Gu et al., 1999; Jing et al., 2010; Zhang et al., 2010; Bai et al., 2012). The calculation is performed deriving the diffuse PAR radiation from the 

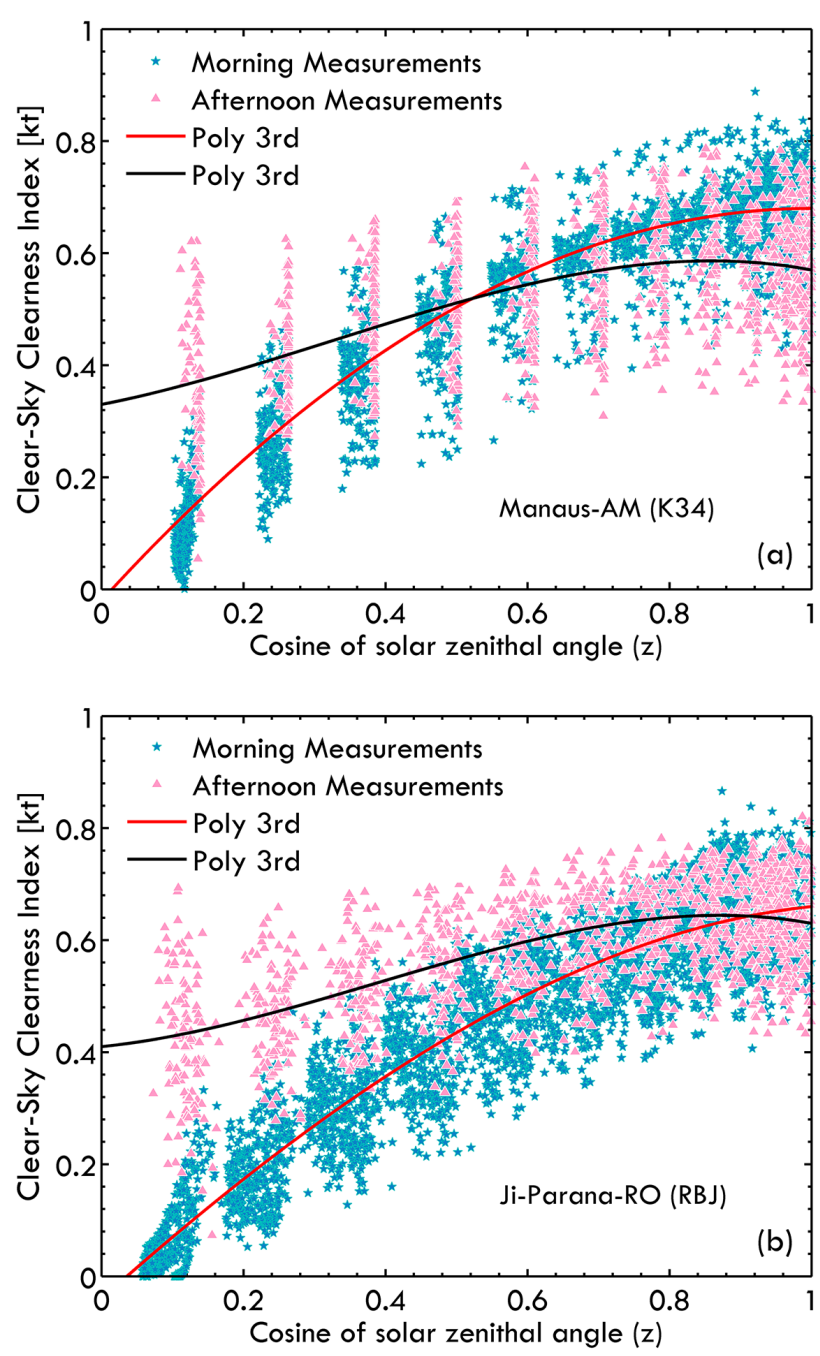

Figure 2. Scatter plots and regressions between clear-sky clearness index and the cosine of solar zenithal angle for the K34 site near Manaus (2000-2009) (a) and for the RBJ site in Ji-Parana (20002002) (b).

following formulation (Spitters, 1986):

$\operatorname{PAR}_{\mathrm{f}}=\left[\frac{\left[1+0.3\left(1-q^{2}\right)\right] q}{1+\left(1-q^{2}\right) \cos ^{2}\left(90^{\circ}-z\right) \cos ^{3} z}\right] \times \mathrm{PAR}_{\mathrm{t}}$,

where $\mathrm{PAR}_{\mathrm{f}}$ is the diffuse PAR radiation flux $\left(\mu\right.$ mol photon $\mathrm{m}^{-2} \mathrm{~s}$ ) and the parameter " $q$ " is a proportionality coefficient used to denote the ratio of total diffuse radiation to a given amount of irradiance $(S)$ that reached surface under a given sky condition $\left(\mathrm{Wm}^{-2}\right)$. The parameter $q$ can be expressed from the following equation:

$q=\left(S_{\mathrm{f}} / S_{\mathrm{e}}\right) / k t$,

where $S_{\mathrm{f}}$ denotes the total diffuse radiation (visible plus nearinfrared) received on a horizontal plane at the Earth surface $\left(\mathrm{W} \mathrm{m}^{-2}\right)$. The parameters " $S_{\mathrm{e}}$ " (solar irradiance on TOA)
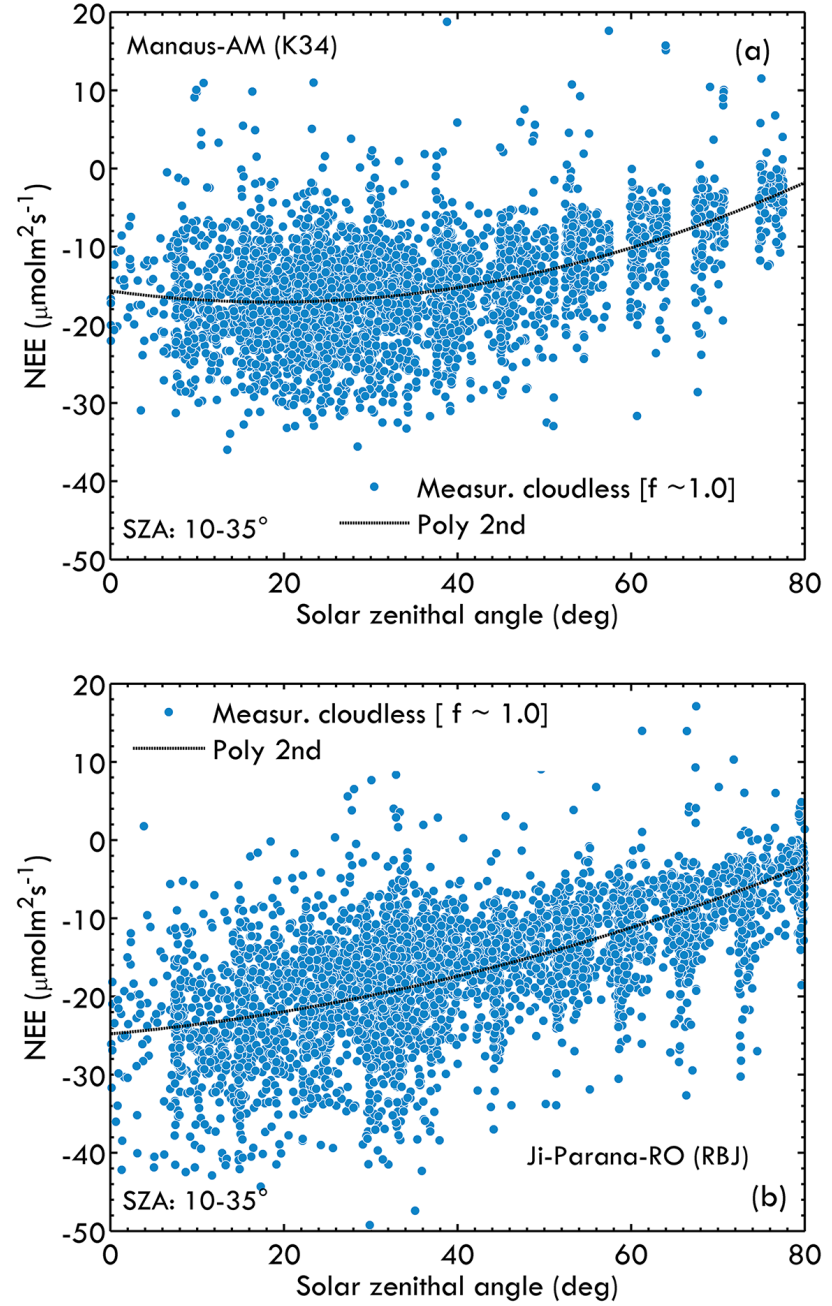

Figure 3. Relationship between NEE and solar zenithal angle (SZA) for clear-sky conditions $(f=1.0)$ at $\mathrm{K} 34$ (a) for a poly 2 nd fit with $R^{2}=0.27$ and $p<0.01$, and at the RBJ (b) for a 2 nd order polynomial fit with $R^{2}=0.60$ and $p<0.001$.

and " $k t$ " (the clearness index) are the same parameters defined previously in Sect. 2.3.3. Another important parameter in this kind of study is the light use efficiency (LUE), which expresses the efficiency of light use into photosynthetic processes by the canopy. It is defined as the ratio between NEE and $\mathrm{PAR}_{\mathrm{t}}$ :

$\mathrm{LUE}=\mathrm{NEE} / \mathrm{PAR}_{\mathrm{t}}$

To evaluate the effect of diffuse PAR radiation $\left(\mathrm{PAR}_{\mathrm{f}}\right)$ on LUE, it is common to define the parameter $D_{\mathrm{f}}$, which is the ratio between $\left(\mathrm{PAR}_{\mathrm{f}}\right)$ and total PAR $\left(\mathrm{PAR}_{\mathrm{t}}\right)$ (Jing et al., 2010):

$D_{\mathrm{f}}=\mathrm{PAR}_{\mathrm{f}} / \mathrm{PAR}_{\mathrm{t}}$. 
Table 3. Regression coefficients of relationship between NEE and solar zenithal angle (SZA) for clear-sky conditions $(f \sim 1.0)$ observed during the year at the K34 and RBJ sites. The fitted equation is NEE $=\mathrm{n}_{3}+\mathrm{n}_{2}(\mathrm{SZA})+\mathrm{n}_{1}(\mathrm{SZA})^{2}$.

\begin{tabular}{|c|c|c|c|c|}
\hline \multirow{2}{*}{$\begin{array}{l}\text { Measurements (morning) } \\
\text { Clear-sky }\end{array}$} & \multicolumn{4}{|c|}{ Regression of parameters } \\
\hline & $\mathrm{n}_{1}^{*}$ & $\mathrm{n}_{2}^{*}$ & $\mathrm{n}_{3}^{*}$ & $R$-squared \\
\hline \multicolumn{5}{|c|}{ Trop. Rainforest (RBJ)/2000-2002 } \\
\hline $\mathrm{NEE}$ of $\mathrm{CO}_{2}-\mu \mathrm{mol} \mathrm{m}{ }^{-2} \mathrm{~s}^{-1}$ & 0.002 & 0.100 & -24.8 & 0.60 \\
\hline \multicolumn{5}{|c|}{ Trop. Rainforest (K34)/2000-2009 } \\
\hline $\mathrm{NEE}$ of $\mathrm{CO}_{2}-\mu \mathrm{mol} \mathrm{m}{ }^{-2} \mathrm{~s}^{-1}$ & 0.004 & -0.152 & -15.7 & 0.27 \\
\hline
\end{tabular}

\subsubsection{Canopy top temperature}

As there are no direct measurements of skin temperature of the canopy at either study sites, we used the data sets of pyrgeometers operated above the canopy on both sites (Table 1) to measure the emission of long wave radiation from the surface $(L \uparrow)\left(\mathrm{W} \mathrm{m}^{-2}\right)$. Equation (13) was derived from the Stefan-Boltzmann equation and used to calculate the temperature of the canopy $\left(T_{\mathrm{c}}\right)$ of the $\mathrm{K} 34$ and RBJ sites.

$T_{\mathrm{c}}=(L \uparrow / \sigma \varepsilon)^{0.25}$,

where $\varepsilon$ is the emissivity, assumed 0.98 (Monteith and Unsworth, 1990) and $\sigma$ the Stefan-Boltzmann constant $\left(5.670 \times 10^{-8} \mathrm{~W} \mathrm{~m}^{-2} \mathrm{~K}^{4}\right)$. Dougthy et al. (2010) used similar procedures to estimate the canopy temperature (skin temperature) in Tapajos National Forest (Santarem-PA).

\section{Results and discussions}

The first task was to validate MODIS AOD estimations with the AOD measurements from the AERONET sun photometer network. Following this, the radiative effects of aerosols and clouds on the $\mathrm{CO}_{2}$ fluxes for both sites were analyzed. Measurements of NEE, $\mathrm{PAR}_{t}, \mathrm{PAR}_{\mathrm{f}}, \mathrm{AOD}$, relative humidity, air temperature and surface temperature of the forest canopy were further analyzed as a function of the relative irradiance parameter $(f)$, during the whole year for wet, dry and transition seasons.

\subsection{The diurnal cycle of net ecosystem exchange}

Figure 4 shows the diurnal cycle of NEE during the wet and dry season at both sites. The diurnal cycle of NEE is typical for tropical forests, with the magnitudes and peak hours of carbon absorption consistent with previous observations in other areas of the Brazilian Amazon forest (de Araújo et al., 2010; Hutyra et al., 2008; von Randow et al., 2004; Vourlitis et al., 2011). Net ecosystem exchange is negative during daytime when photosynthesis is larger than respiration. During nighttime, $\mathrm{CO}_{2}$ fluxes are predominantly positive with $\mathrm{CO}_{2}$ being released to the atmosphere. Differences in respiration values between the two locations are associated with both the intrinsic physiological characteristics of both ecosystems as well as issues associated with the topographic complexity in the Manaus K34 area (von Randow et al., 2004; Tóta et al., 2008; de Araújo et al., 2010; Mahrt, 2010). It was also possible to observe over the dry season that the maximum carbon absorption (negative values) does not occur at local solar noon, but often around 10:00 LT, at both sites. On the other hand, during the wet season, the maximum negative values of NEE were observed around 11:00-12:00 LT. This indicates a possible connection between biotic and physical factors with a possible ecophysiological response of vegetation to higher availability of incoming radiation in the dry period (da Rocha et al., 2004, 2009; de Araújo et al., 2010). Large variability in $\mathrm{CO}_{2}$ fluxes during the first hours of the day, with larger standard deviations compared to nighttime values, was observed (Fig. 4). This is due to early morning turbulence at the canopy level and the breakup of the nocturnal boundary layer and the beginning of the daytime boundary layer (Betts and Dias, 2010).

\subsection{MODIS AOD validation for the central and southwestern Amazon}

The estimates of the MODIS AOD allowed observing the atmospheric aerosol loadings from two geographic regions with very different characteristics. One region less impacted by anthropogenic activities (Manaus and Balbina), central Amazon (Fig. 5a), and the other, heavily impacted by biomass burning smoke, represented by the site RBJ in Rondonia (Fig. 5c). Balbina (coordinates $1^{\circ} 55^{\prime} 1.14^{\prime \prime} \mathrm{S}$ and $59^{\circ} 29^{\prime} 12.48^{\prime \prime} \mathrm{W}$ ) is a site close to K34, where AERONET AOD measurements were taken from 2000 to 2002. During the wet season, AOD values were small (around 0.10, a typical background value for the Amazon), but increased significantly during the dry season with the long-range transport of biomass burning aerosol emissions. During the dry season, 

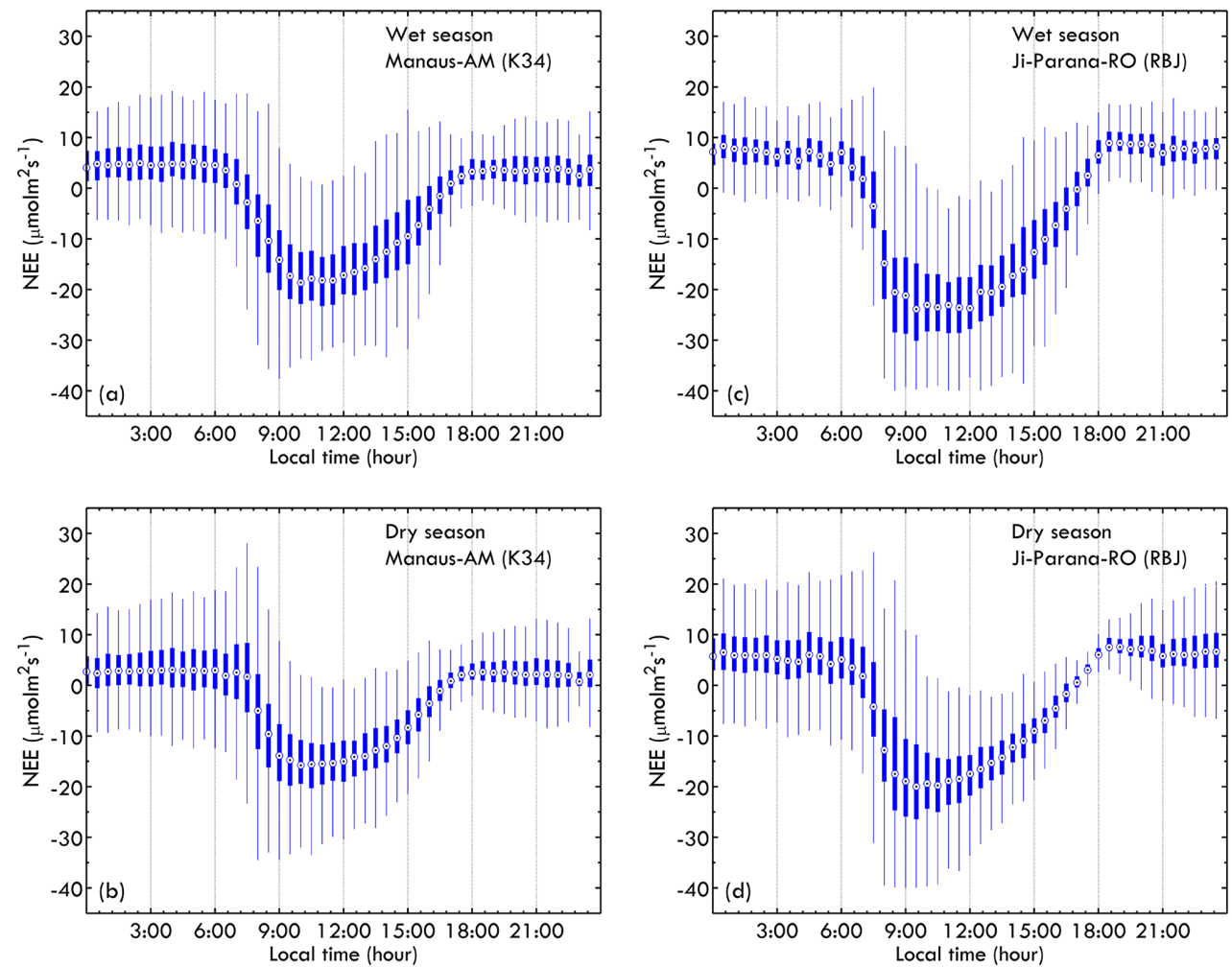

Figure 4. Seasonally averaged diurnal cycles of NEE for the wet and dry seasons in the tropical rainforests in Manaus/K34 (1999-2009), (a) and (b), and in Ji-Parana/RBJ (1999-2002), (c) and (d).

daily average AOD reached high values at $\mathrm{RBJ}$ (greater than 3.5) and at K34 (around 1.5) (Fig. 5a and c). These high atmospheric aerosol loadings from biomass burning cover very large areas of South America, and have impacts far from their source regions (Artaxo et al., 1998, 2002; Procopio et al., 2004; Martin et al., 2010a, b; Davidson et al., 2012).

Figure $5 b$ and $d$ show that for both sites used in this study, MODIS and AERONET AOD agree quite well, with values of $R^{2}$ that are statistically significant at the $95 \%$ confidence level. In general, MODIS values tend to overestimate the AOD measurements at the two sites at $550 \mathrm{~nm}$. The systematic errors (mean absolute error - MAE) of the estimates of AOD with MODIS shows values around 5-10\% higher than AERONET measurements. This difference is considered acceptable in similar AERONET versus MODIS comparisons (Chu et al., 2002). The largest errors occur for AOD values greater than 1.0, where in some cases the MODIS values are higher than AERONET measurements by up to a factor of 2 (Fig. 5d). The regression analysis presented in Fig. 5b and $\mathrm{d}$ shows that MODIS can be used to derive AOD, taking AERONET values as a reference (Remer et al., 2013).

\subsection{The influence of aerosols and clouds on PAR radiation and relative irradiance}

The impact of aerosols from biomass burning emissions on the radiation budget was assessed in terms of incident solar irradiance represented by the relative irradiance parameter $f$, PARt and PAR . The behavior of the relative irradiance $f$ as a function of AOD, under minimal cloud effects, is shown in Fig. 6a and b for K34 and RBJ, respectively. In spite of the relatively large scattering, it is possible to observe a linear relationship in which $f$ decreases with the increase of the AOD at both sites. The linear relationship between $f$ and AOD is statistically significant with $p$ values $<0.01$ with a $\mathrm{R}^{2}$ of about $0.22(\mathrm{~K} 34)$ and $\sim 0.37(\mathrm{RBJ})$. At $\cos (z)$ values for $z$ between 10 and $35^{\circ}$, a reduction in the value of $f$ on the order of $25 \%$ was observed when the AOD varied from $\sim 0$ to 0.70 at the site of K34 (Fig. 6a) and $\sim 0$ to 2.5 in the forest area of RBJ. Oliveira et al. (2007) showed similar decreases $(\sim 20 \%)$ when $f$ varied from $\sim 1.1$ to 0.80 .

Figure $6 \mathrm{c}$ and $\mathrm{d}$ show the calculated fraction of diffuse radiation as a function of AOD. The calculation shows an increase of about $25 \%$ in diffuse radiation when the AOD increases from $\sim 0$ to $0.70(\mathrm{~K} 34)$ and from $\sim 0$ to 2.5 (RBJ). These results are particularly important because diffuse PAR penetrates more efficiently in the canopy and contributes to an increase in carbon uptake (Doughty et al., 2010). The joint 

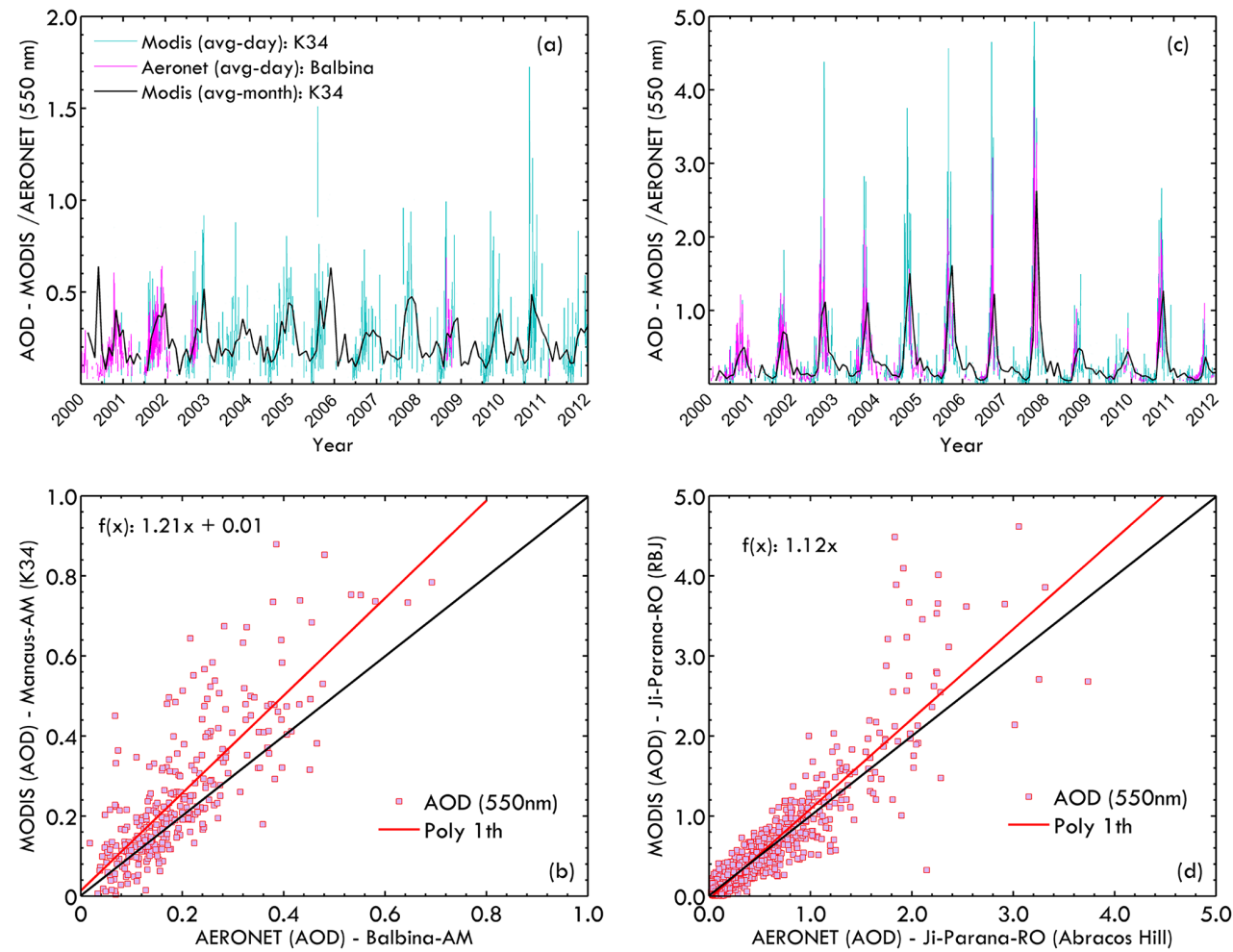

Figure 5. Time series of AOD (at $550 \mathrm{~nm}$ ) from 2000 to 2012 estimated by MODIS and measured by the AERONET sun photometer at $550 \mathrm{~nm}$ at the K34 site (a) and at the RBJ site (c). Panels (b) and (d) show regressions of the estimation of AOD by MODIS at K34 (b) and at RBJ (d). The red lines represent the linear fits at both sites, with $R^{2}$ equal 0.64 (K34) and 0.84 (RBJ). The AOD values (AERONET) at $550 \mathrm{~nm}$ were calculated through Ångström $\alpha \sim 1.01$ at the Balbina-AM site (b) and $\alpha \sim 1.48$ at the Abracos Hill (d) site. The differences between linear fit found between the estimates made by the MODIS $(550 \mathrm{~nm})$ and by sun photometer AERONET (500 nm) are less than $\sim 5 \%$ (results not shown).

analyses of Fig. 6 with the results shown in Sect. 3.5 help to explain how the increase in AOD and $\mathrm{PAR}_{\mathrm{f}}$ affects carbon uptake by the forest.

Figure $7 \mathrm{a}$ and $\mathrm{b}$ show that for $f$ ranging from 0.80 to $\sim 1.2$, the PAR $_{\mathrm{t}}$ is reduced by approximately $35 \%$ at both K34 and RBJ. This behavior was observed both during the biomass burning season and the wet season. These figures also show a strong reduction in $\mathrm{PAR}_{\mathrm{t}}$ when the cloud cover changes from a clear-sky conditions (AOD $\sim 0.10, f \sim 1.0$ ) to completely overcast by clouds and aerosols $(\mathrm{AOD} \gg 0.10$, $f<1.0$ ). Although the PAR $_{\mathrm{t}}$ decreases almost linearly with the relative irradiance (Fig. 7a and b), the relationship between the diffuse PAR radiation and $f$ is not linear (Fig. 7c and d). At K34, the PAR $\mathrm{f}_{\mathrm{f}}$ increases $510 \mu \mathrm{mol} \mathrm{m}^{-2} \mathrm{~s}^{-1}$ when the relative irradiance $f$ decreases from 1.1 to 0.72 . This corresponds to a $50 \%$ increase in PAR (diffuse) due to scattering by aerosols and clouds during wet and biomass burning season. At RBJ, a $47 \%$ increase in PAR (diffuse) was observed when $f$ decreases from 1.1 to $0.68\left(\sim 468 \mu \mathrm{mol} \mathrm{m}^{-2} \mathrm{~s}^{-1}\right)$. At this site, these changes are mainly due to the dense aerosol layer observed during the biomass burning season.

\subsection{The effect of PAR (diffuse) radiation on the light use efficiency (LUE) through the forest}

In Sects. 3.2 and 3.3, strong AOD seasonality was observed, with important effects on the atmospheric radiation balance and, in particular, on PAR flux radiation. In this section, the effects of these changes on the efficiency of radiation used by forests (LUE) were evaluated and the values of radiation efficiency use for which this efficiency is maximum were identified.

Figure 8a and $\mathrm{b}$ show NEE as a function of total PAR observed during clear-sky days and during cloudy days and/or days with high aerosol loading, in the wet season and in the transition and dry season for both K34 and RBJ. Under smokey or cloudy sky condition the assimilation of carbon gradually increases with increasing total PAR radiation $\left(\mathrm{PAR}_{\mathrm{t}}\right)$ reaching its maximum saturation at around 1550 and $1870 \mu \mathrm{mol} \mathrm{m}^{-2} \mathrm{~s}^{-1}$, in the which the NEE values are -20 and $-23 \mu \mathrm{mol} \mathrm{m}^{-2} \mathrm{~s}^{-1}$ at $\mathrm{K} 34$ and RBJ, respectively (Fig. 8a and b). Under clear-sky conditions, the maximum saturation (maximum negative NEE) occurs around $\sim 2100$ $2300 \mu \mathrm{mol} \mathrm{m}^{-2} \mathrm{~s}^{-1}$, that is, close to $-18 \mu \mathrm{mol} \mathrm{m}^{-2} \mathrm{~s}$ at both 

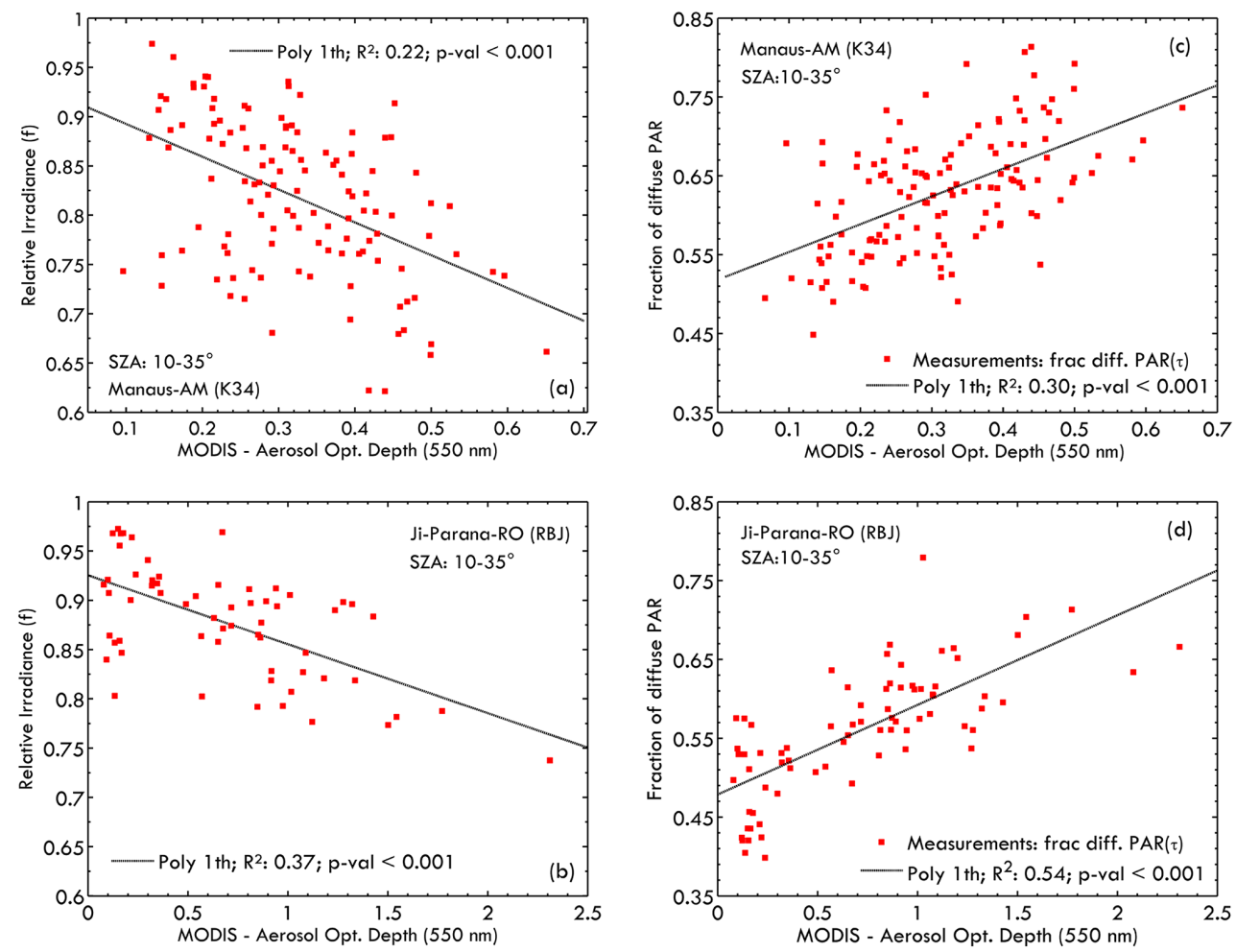

Figure 6. Relationships between relative irradiance $f$ and AOD (MODIS) for Manaus-K34 (a) and Ji-Parana (RBJ) (b). The lower part shows the fraction of diffuse PAR for K34 (c) (2000-2009) and RBJ (d) (2000-2002).

sites. Figure $8 \mathrm{a}$ and $\mathrm{b}$ show that the forests do not reach the maximum negative NEE on clear-sky days but during smokey or overcast conditions, where it was observed that lesser amounts of energy are required for forests to reach the maximal saturation (Fig. 8a and b). These results show that the fraction of diffuse solar radiation strongly affects the NEE at both sites in the Amazon.

Figure $8 \mathrm{c}$ and $\mathrm{d}$ show the NEE normalized by the total PAR flux plotted against the diffuse fraction of PAR radiation. It is possible to analyze vegetation LUE by analyzing the ratio of NEE/PAR-total (Jing et al., 2010). This relationship represents the photosynthetic efficiency, which is related to the ability of the canopy to convert solar energy into biomass. At both sites it is possible to observe that LUE is low $(\sim 1-2 \%)$, requiring large amounts of energy for photosynthesis. Furthermore, peaks of up to $4 \%$ (K34) and $6 \%$ (RBJ) in photosynthetic efficiency were observed in cases where the diffuse fraction reaches values around 1 during situations when the sky is obscured by clouds and/or aerosols $(f<1.0$, AOD $>0.10)$. A gradual increase in LUE was observed (Fig. 8c and d) with increasing PAR (diffused) for irradiance values around 0.80 , falling sharply after this value until the maximum fraction $\mathrm{PAR}_{\mathrm{f}}$ which is 1.0 . These results are similar to those obtained in the semiarid region of northeastern China (Jing et al., 2010).

\subsection{Effects of aerosols and clouds on the net ecosystem exchange}

Figure 9a and $\mathrm{b}$ show the relationship between NEE and relative irradiance $f$ for the experimental forest sites K34 and RBJ. In Fig. 9c and $d$ the changes in net carbon absorbed by these forests (relative change of NEE, NEE (\%)) due to aerosols (green dots) and clouds (black dots) can be observed. These analyses were performed with the combined effects of clouds and aerosols. Due to the strong aerosolcloud interactions in the Amazon (Andreae et al., 2004; Koren et al., 2008, 2009), it was not possible to fully separate the aerosol and cloud effects. Both affect the radiation balance in different ways and are intrinsically connected (Boucher et al., 2014). Also, both influence atmospheric thermodynamic properties through complex and not well-understood mechanisms. It is possible to observe at both sites that NEE has an inflection point at around $f \sim 0.8$. In other words, the maximum $\mathrm{CO}_{2}$ fixation does not occur on a clear day $(\sim f$ 1.0 and $\mathrm{AOD}<0.10$ ), but on days with either minimal cloud cover and/or moderate aerosol loading which increases the diffuse fraction of solar radiation. This effect was observed at both sites, during the dry season when there is a large loading of aerosols in the atmosphere and low cloud cover percentage, and during the wet season, which experiences minimal aerosol content and frequent cloud cover (Figs. 5a and c, 10a 

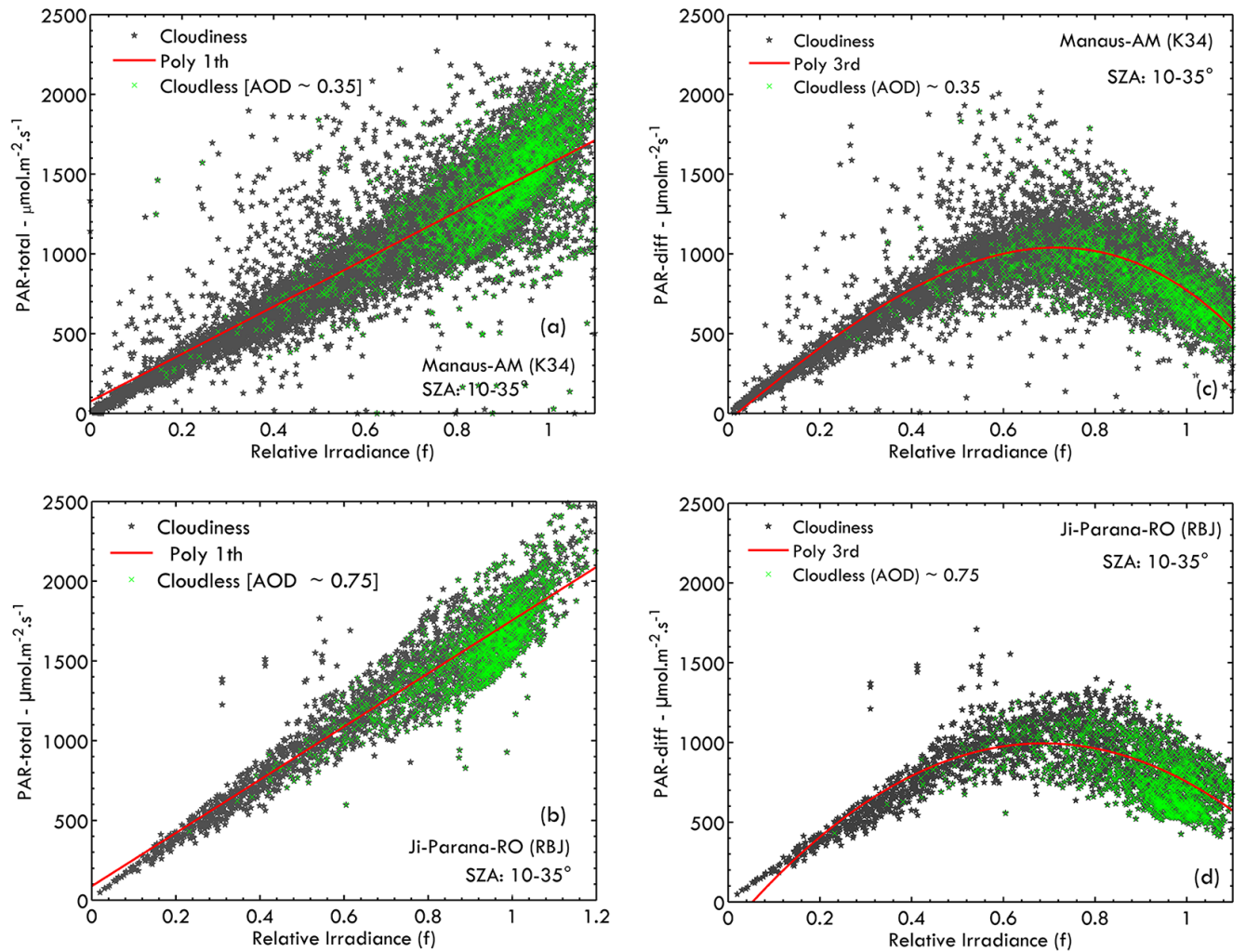

Figure 7. Relationships between total PAR and relative irradiance $f$ for the K34 site (a) and RBJ (b). The lower part shows the diffuse PAR versus relative irradiance $f$ for K34 (c) and RBJ (d) sites. The periods of the data used are K34 site (2000-2009) and RBJ site (2000-2002).

and b). However, this enhancement in NEE appears to occur from $f$ values from 1.0 to $\sim 0.8$. For further reduction in the radiation field, the enhanced diffuse radiation does not compensate for the reduced total flux of solar radiation, and the photosynthesis process is severally reduced (Fig. 9a and b). In short, diffuse radiation $\left(\mathrm{PAR}_{\mathrm{f}}\right)$ increases the rate of photosynthesis only until a certain level of aerosol loading. A similar effect was also observed by Gu et al. 1999 and Doughty et al., 2010.

\subsection{The net uptake of $\mathrm{CO}_{2}$ due to aerosols and clouds}

Through the use of Eqs. (1) and (8) it is possible to calculate the ratio of NEE $(\%)$ and the relative irradiance $(f)$ for various intervals of zenithal angle. This procedure was adopted to minimize the effects of solar elevation throughout the day on NEE. For each solar zenithal angle (SZA) interval analyzed, the average NEE (\%) for the relative irradiance $f$ in bins equal to 0.1 (Fig. 9a and b) were calculated separately. At $\mathrm{K} 34$, an average increase of approximately $20 \%$ in carbon uptake was observed relative to clear-sky ( $\left.\mathrm{NEE}_{\mathrm{csky}}\right)$ conditions when the $f$ is reduced from $\sim 1.1$ to 0.8 (Fig. 9c). For this range of variation in $f$, AOD increases from $\sim 0.10$ to 0.70 (Fig. 6a) and produces significant reductions in total PAR radiation flux $\left(\mathrm{PAR}_{\mathrm{t}}\right)$, of approximately $35 \%$ and, concomitantly, an increase of up to $50 \%$ in PAR $_{\mathrm{f}}$ (Fig. 7a and c). At RBJ, the relative increase of NEE (\%) is about $30 \%$ when $f$ varies from $\sim 1.1$ to 0.80 (Fig. $9 \mathrm{~d}$ ). In the latter case, considering these same variations in $f$, the aerosol loading in the atmosphere increases AOD from 0.10 to 2.5 (Fig. 6b) producing also reductions of up to $35 \%$ of PAR and an increase of $47 \%$ in PAR $_{\mathrm{f}}$ (Fig. $7 \mathrm{~b}$ and $\mathrm{d}$ ). The increase in carbon uptake in the presence of aerosols and clouds becomes smaller and similar in both sites for solar zenithal angles $<20^{\circ}$ (Fig. 9c and d). Near zenith, solar radiation is less scattered by particles suspended in the atmosphere due to decreased path length, mitigating the diffuse radiation effects on the photosynthetic process.

The results from Fig. 9 show that the photosynthetic efficiency of the forest is relatively larger on days with the atmosphere loaded with small amounts of aerosol particles and/or less cloud cover. The effect is clearly nonlinear, reaching a point where NEE begins to decrease. The value of this behavior varies for each solar zenith angle range. For measurements between 10 and $20^{\circ}$, a reduction in solar irradiance of up to $30 \%$ does not inhibit $\mathrm{CO}_{2}$ uptake in the forest canopy. For measurements taken for solar zenith angle between 20 and $35^{\circ}$, a $40 \%$ reduction in irradiance does not show effects on $\mathrm{CO}_{2}$ uptake. This result is important since much of the Amazon area is often impacted by the presence of aerosols 

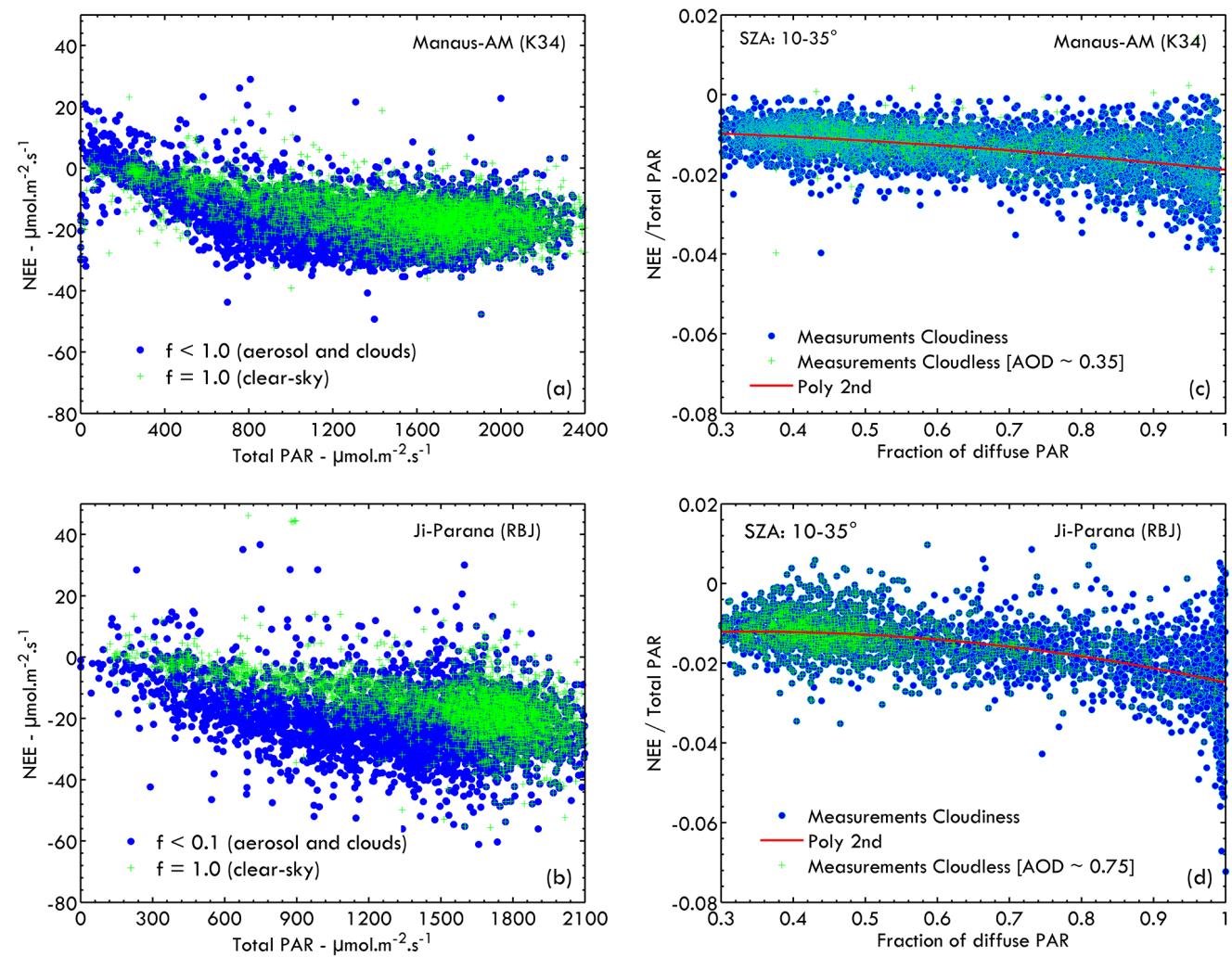

Figure 8. NEE as a function of total downward PAR radiation for measurements between the 08:30 and 17:30 LT for the K34 (a) and RBJ (b) sites. Panels (c) and (d) show the LUE of vegetation as a function of the fraction of diffuse PAR at K34 $\left(R^{2}=0.21, p\right.$ value $\left.<0.001\right)$ in Manaus (2000-2009) (c) and RBJ $\left(R^{2}=0.30, p\right.$ value $\left.<0.001\right)$ in Ji-Parana (2000-2002).

in small amounts (low AOD) similar to those observed for Manaus. The increases in $\mathrm{CO}_{2}$ uptake are significant and could have major impacts on the Amazon forest carbon budget. Peak $\mathrm{CO}_{2}$ uptake is often observed for $f$ values near 0.80 , a value typically encountered in dense forest ecosystems (Gu et al., 1999; Yamasoe et al., 2006; Oliveira et al., 2007; Doughty et al., 2010) but quite different from what is found in grasslands and other temperate forested regions (Niyogi, 2004; Jing et al., 2010; Zhang et al., 2010).

\subsection{The relationship between the current patterns of aerosols and clouds and carbon uptake}

Figure 10 shows the percentage distribution of the $k t$ (clearness index) throughout the year at K34 (2000-2009) and RBJ (2000-2002) sites. The percentage of cloud cover (not shown), as well as the distributions of $k t$ (Fig. 10a and b) are similar for both sites, but differ from wet and dry seasons, as expected. Using brightness temperature from GOES10, $60 \%$ of the time during the rainy season, both K34 and RBJ experienced some degree of cloud cover. This percentage, decreases during the dry season (August through October) reaching a minimum of $20 \%$ at RBJ and $30 \%$ at K34 in September. The frequency distribution of $k t$ (Fig. 10a and b) is compatible with the observations of cloud cover observed using GOES10 analysis (around 60-70\%).

The analysis of $k t$ frequency distributions (Fig. 10a and b) indicates that current patterns of cloudiness do not yet exceed the maximum limit for which the forests of K34 and RBJ sites reach the maximum amounts of carbon uptake. The peak $k t$ distribution at both sites is near 0.75 (Fig. 10b), which is smaller than the values of $f$ for which the NEE reaches its maximum negative value during the burning season $(k t \sim 0.57)$. This is the limit at which the cloudiness and/or aerosol load result in the maximum carbon uptake at RBJ and K34 (Fig. 10c). Larger quantities of aerosols and clouds in the region could cause these forests to absorb even greater amounts of carbon throughout the day, considering the combined effect of NEE enhancement by aerosols and clouds. The distribution patterns of the occurrence frequency of $k t$ found throughout the years at both forest sites (Fig. 10) are similar to those found by Oliveira et al. (2007) in the Tapajos National Forest in Santarem and also RBJ in Rondonia. These results are also consistent with calculations from $\mathrm{Gu}$ et al. (1999) in temperate forests of Canada, where $k t$ values are centered at 0.75 and the maximum negative NEE is at about $0.55-0.60$. 

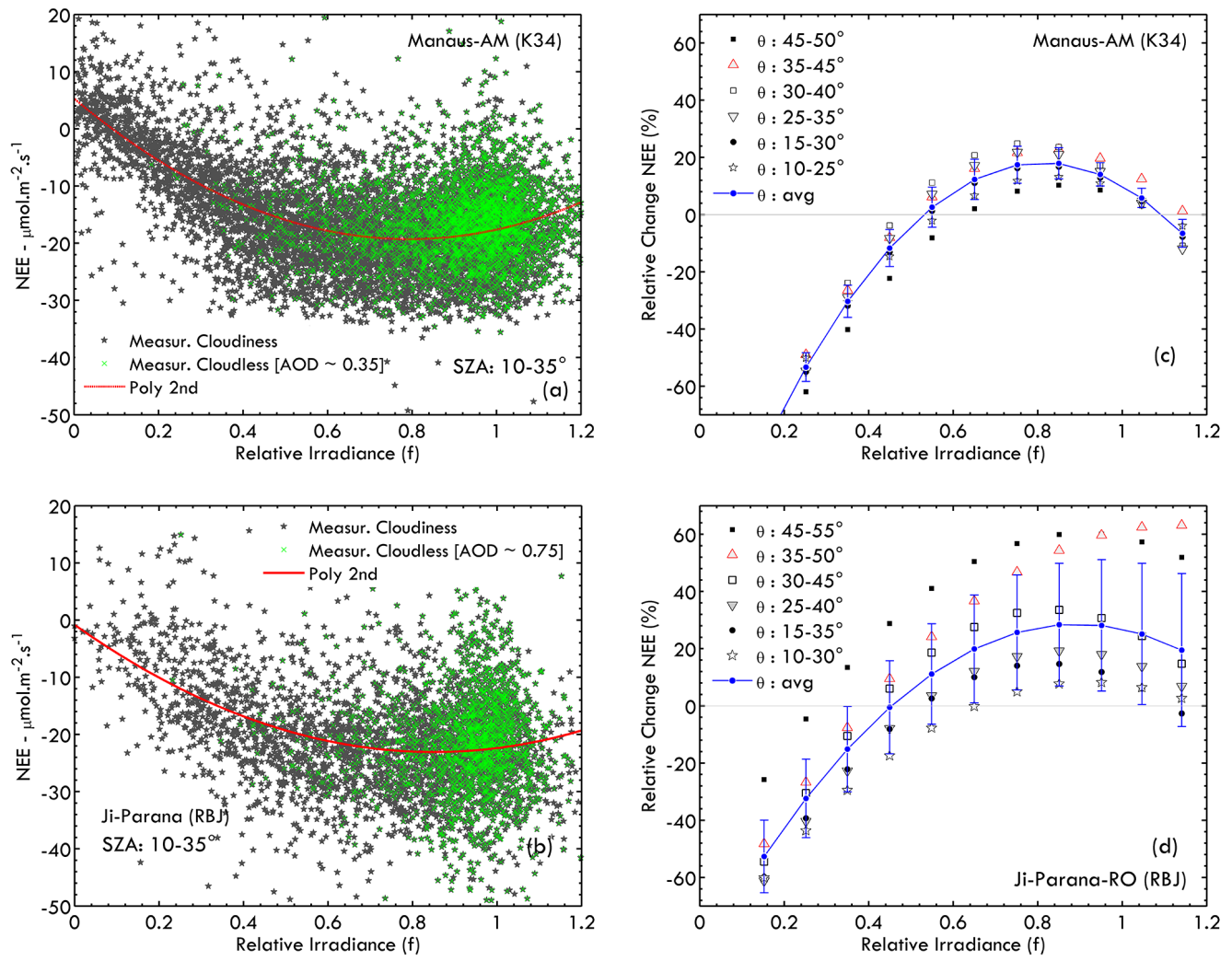

Figure 9. Variability of NEE with the relative irradiance $f$ for the K34 /Manaus $\left(R^{2}=0.32\right)$ and RBJ/Ji-Parana $\left(R^{2}=0.12\right)$ sites for solar zenithal angle interval $(z)$ between $10^{\circ}$ and $35^{\circ}-(\mathbf{a})$ and (b). Relative change of NEE (\%NEE) as a function of the relative irradiance $f$, averaged for all solar zenithal angle intervals $(z)$, from $10^{\circ}$ to $55^{\circ}-(\mathbf{c})$ and (d). Note that this plot includes cloud and aerosol effects.

The yearly variability of the relationship between observed AOD, fire counts and NEE for the long time series of 10 years at K34 was also analyzed. A significant year-to-year variability and some stronger NEE in days with high fire counts was observed. However, hydric stress also plays a major role in carbon update (Gatti et al., 2014) that confounds the effects of aerosols on NEE in terms of attribution. More studies are necessary to address the interannual variability.

\subsection{Aerosols and cloud effects on temperature and VPD}

Figure 11 shows the direct influence that clouds and aerosols have on some of the major environmental factors that also affects the photosynthetic activity of plants. The attenuation of incident solar irradiance due to the presence of aerosols and clouds cause significant reductions in air temperature near the forest canopy and also in the vapor pressure deficit (VPD) associated with relative humidity (Fig. 11). At the K34 site, the combined effects of aerosols and clouds (in this case, more aerosols than clouds) produced, respectively, a cooling of 1.8 and $2.5^{\circ} \mathrm{C}$ in air temperature of the canopy when $f$ ranged from $\sim 1.2$ to 0.80 (Fig. 11a and c). At RBJ, considering the same variations in $f$, a cooling of up to $3-$
$4{ }^{\circ} \mathrm{C}$ was observed (Fig. $11 \mathrm{~b}$ and d). These values are on the relatively high side, but are similar to results found by $\mathrm{Da}-$ vidi et al. (2009). Another factor that can increase canopy photosynthesis is the general trend of decreasing vapor pressure deficit on cloudy or smoke-filled skies (Min and Wang, 2005, 2008; Bai, et al., 2012). Figure 11e and f show the relationship between the VPD and irradiance on $f$ (again, between solar zenithal angles 10 and $35^{\circ}$ ). For Freedman et al. (1998), increasing relative humidity due to cloud/aerosolinduced cooling (Altaratz et al., 2008) can increase photosynthesis since this increase naturally induces the opening of the stomata of the leaves (Collatz et al., 1991). At both sites, the reduction in $f$ produced a decrease in VPD around $35 \%$ during the dry season. The reductions observed in the vapor pressure deficit associated with reductions in air temperature in the forest canopy can also be contributing to an increase in NEE, and the general decreasing trends in VPD under cloudy and overcast conditions can induce stomatal openness and thus enhance leaf photosynthesis (Jing et al., 2010). 

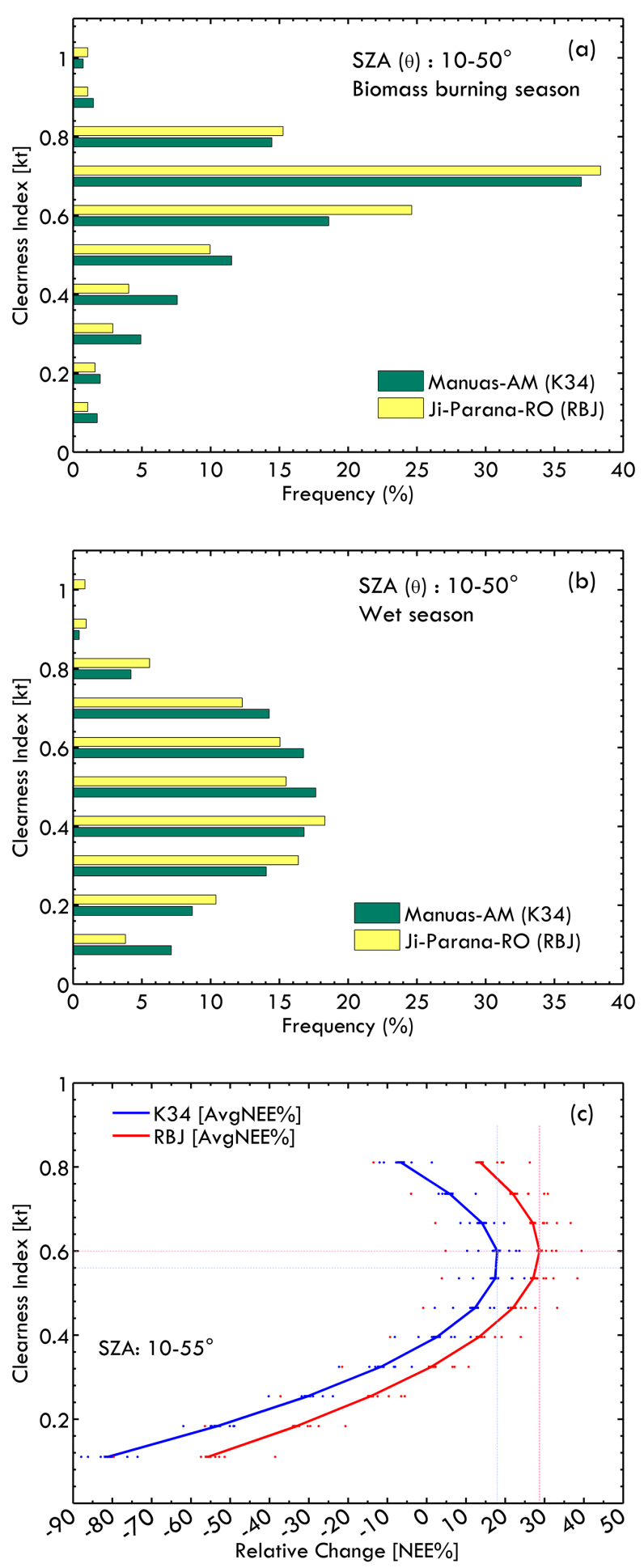

Figure 10. Histograms of values of the clearness index for K34 and RBJ along the biomass burning season (a) and wet season (b). The limit at which the cloudiness and/or aerosol load result in the maximum carbon uptake at RBJ and K34 are shown in (c). The relative change values (NEE (\%)) were calculated for solar zenithal angles between $10^{\circ}$ and $55^{\circ}$.

\section{Conclusions}

Aerosol optical depth derived by MODIS has been shown to be satisfactory for two different sites in the Amazon when compared with AERONET AOD. This allows for the expansion of studies of aerosol effects on tropical ecosystems to other areas of the Amazon, where no AERONET AOD measurements exist. Given the long time series of micrometeorological measurements at the $\mathrm{K} 34$ and RBJ sites, it was possible to assess the reduction in solar irradiance due to the presence of clouds and aerosols emitted by biomass burning. The clear-sky irradiance algorithm developed was able to satisfactorily quantify the reduction in surface radiation flux, taking into account an atmosphere free of clouds and with minimal aerosol loading. Thus, the changes in incident solar radiation and $\mathrm{CO}_{2}$ flux (NEE) could be attributed to the combined effects of clouds and aerosol. In the central Amazon (K34 site), the net carbon flux (NEE) increased by $20 \%$ when the optical depth ranged from $\sim 0.1$ to 0.70 . At the RBJ site, a stronger effect was observed, with an increase of $29 \%$ on the NEE observed when AOD varied between $\sim 0.1$ and 2.5. Clouds and aerosols from biomass burning produced up to a $35 \%$ reduction in the amount of total PAR radiation and also an increase of up to $50 \%$ in the fraction of diffuse PAR radiation, which is utilized more efficiently by the forest photosynthesis process. The results show higher photosynthetic efficiency in situations where the atmosphere is lightly loaded with particles and/or clouds. A more efficient use of the diffuse solar radiation can be pointed to as the main source of increased $\mathrm{CO}_{2}$ flux in the forest areas of the sites studied. The enhancement in diffuse PAR can occur through increase in aerosols or clouds. In the present study, it was not possible to separate these two components. In addition, in view of the increased cloudiness and aerosol loading, significant variations were observed in other meteorological variables, such as temperature and VPD. The variations of these quantities may also influence carbon uptake significantly.

The increase in VPD associated with decreased air temperature due to aerosols and clouds may be changing NEE during biomass burning aerosols exposure. Many physiological and environmental factors also are involved in the dynamics and control of carbon fluxes in the Amazon, and therefore attributing and separating the different effects on $\mathrm{CO}_{2}$ fluxes is difficult.

The increase in NEE due to the increased amount of aerosols and clouds constitute an effect of considerable relevance due to the importance of carbon cycling in the Amazon. A regional study of this effect, based on vegetation maps, remote sensing estimates, assimilated meteorological data and environmental modeling, will help to better understanding of how climate and ecosystem functioning in the Amazon are affected by natural and anthropogenic environmental factors. 

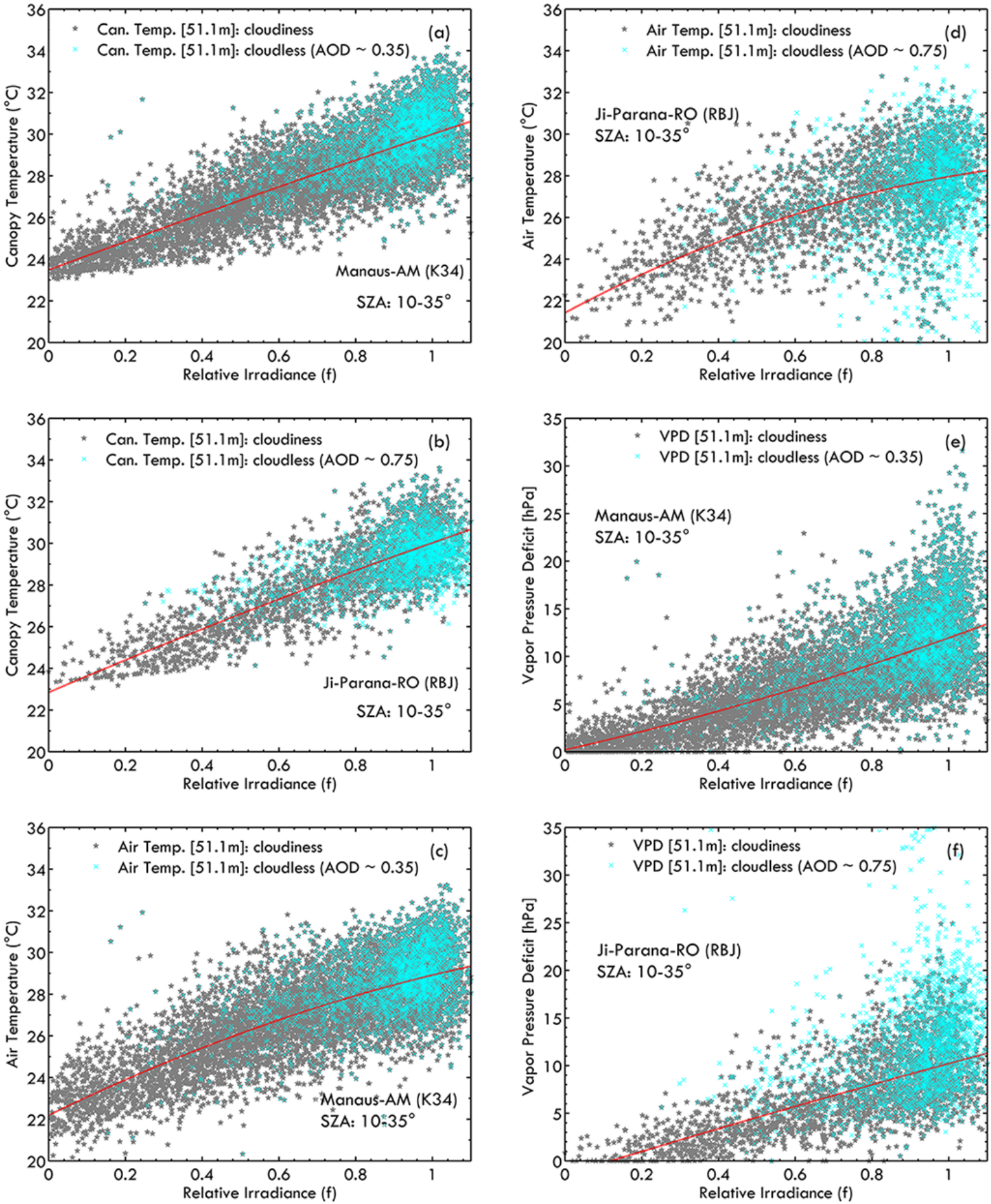

Figure 11. Relationship between the relative irradiance parameter $f$ and: $(\mathbf{a}, \mathbf{b})$ canopy temperature; $(\mathbf{c}, \mathbf{d})$ air temperature and $(\mathbf{e}, \mathbf{f})$ vapor pressure deficit. Values calculated for SZA between 10 and $35^{\circ}$. Air temperature was measured at 51.1 and $60.0 \mathrm{~m}$ above the ground at K34 and RBJ, respectively. 
Acknowledgements. We acknowledge FAPESP projects 2008/58100-2, 2010/52658-1 and 2011/50170-4 for financial support. We also acknowledge financial support from CAPES and CNPq through the projects 477575/2008-0, 475735/2012-9 and the Brazilian National Institute of Science and Technology (INCT) for Climate Change funded by CNPq Grant Number 573797/2008-0 and FAPESP Grant Number 2008/57719-9. We acknowledge the Instituto Nacional de Pesquisas da Amazônia INPA/CLIAMB and the INPA/LBA Central Office for logistical support. We thank several key people for support in aerosol sampling and analysis: Alcides C. Ribeiro, Ana Lucia Loureiro, Fernando G. Morais and Fábio O. Jorge. Thanks go to Luiz Machado, Roberto Freitas (INPE/DSA, Brazil) and Alexandre L. Correia (IF/USP) for GOES and MODIS data.

Edited by: A. B. Guenther

\section{References}

Abakumova, G. M., Feigelson, E. M., Russak, V., and Stadnik, V. V.: Evaluation of long-term changes in radiation, cloudiness, and surface temperature on the territory of the former soviet union, J. Climate, 9, 1319-1327, 1996.

Adams, D. K., Fernandes, R. M. S., and Maia, J. M. F.: GNSS precipitable water vapor from an Amazonian rain forest flux tower, J. Atmos. Ocean. Technol., 28, 1192-1198, doi:10.1175/JtechD-11-00082.1, 2011.

Altaratz, O., Koren, I., and Reisin, T.: Humidity impact on the aerosol effect in warm cumulus clouds, Geophys. Res. Lett., 35, L17804, doi:10.1029/2008g1034178, 2008.

Andreae, M. O., Rosenfeld, D., Artaxo, P., Costa, A. A., Frank, G. P., Longo, K. M., and Silva-Dias, M. A. F.: Smoking rain clouds over the Amazon, Science, 303, 1337-1342, doi:10.1126/science.1092779, 2004.

Araujo, A. C., Nobre, A. D., Kruijt, B., Elbers, J. A., Dallarosa, R., Stefani, P., von Randow, C., Manzi, A. O., Culf, A. D., Gash, J. H. C., Valentini, R., and Kabat, P.: Comparative measurements of carbon dioxide fluxes from two nearby towers in a central Amazonian rainforest: the Manaus LBA site, J. Geophys. Res.Atmos., 107, 8090, doi:10.1029/2001jd000676, 2002.

Artaxo, P., Fernandes, E. T., Martins, J. V., Yamasoe, M. A., Hobbs, P. V., Maenhaut, W., Longo, K. M., and Castanho, A.: Largescale aerosol source apportionment in Amazonia, J. Geophys. Res.-Atmos., 103, 31837-31847, doi:10.1029/98JD02346, 1998.

Artaxo, P., Martins, J. V., Yamasoe, M. A., Procopio, A. S., Pauliquevis, T. M., Andreae, M. O., Guyon, P., Gatti, L. V., and Leal, A. M. C.: Physical and chemical properties of aerosols in the wet and dry seasons in Rondonia, Amazonia, J. Geophys. Res.-Atmos., 107, 8081, doi:10.1029/2001JD000666, 2002.

Artaxo, P., Rizzo, L. V., Paixao, M., de Lucca, S., Oliveira, P. H., Lara, L. L., Wiedemann, K. T., Andreae, M. O., Holben, B., Schafer, J., Correia, A. L., and Pauliquevis, T. M.: Aerosol particles in Amazonia: their composition, role in the radiation balance, cloud formation, and nutrient cycles, Geophys. Monogr. Ser., 186, 233-250, doi:10.1029/2008GM000778, 2009.

Artaxo, P., Rizzo, L. V., Brito, J. F., Barbosa, H. M. J., Arana, A., Sena, E. T., Cirino, G. G., Bastos, W., Martin, S. T., and Andreae, M. O.: Atmospheric aerosols in Amazonia and land use change: from natural biogenic to biomass burning conditions, Faraday Discuss., 165, 203-235, doi:10.1039/C3FD00052D, 2013.

Aubinet, M., Grelle, A., Ibrom, A., Rannik, U., Moncrieff, J., Foken, T., Kowalski, A. S., Martin, P. H., Berbigier, P., Bernhofer, C., Clement, R., Elbers, J., Granier, A., Grunwald, T., Morgenstern, K., Pilegaard, K., Rebmann, C., Snijders, W., Valentini, R., and Vesala, T.: Estimates of the annual net carbon and water exchange of forests: the EUROFLUX methodology, Adv. Ecol. Res., 30, 113-175, 2000.

Aubinet, M., Chermanne, B., Vandenhaute, M., Longdoz, B., Yernaux, M., and Laitat, E.: Long term carbon dioxide exchange above a mixed forest in the Belgian Ardennes, Agr. Forest Meteorol., 108, 293-315, doi:10.1016/S0168-1923(01)00244-1, 2001.

Bai, Y., Wang, J., Zhang, B., Zhang, Z., and Liang, J.: Comparing the impact of cloudiness on carbon dioxide exchange in a grassland and a maize cropland in northwestern China, Ecol. Res., 27, 615-623, doi:10.1007/s11284-012-0930-z, 2012.

Baldocchi, D.: Measuring and modelling carbon dioxide and water vapour exchange over a temperate broad-leaved forest during the 1995 summer drought, Plant Cell Environ., 20, 1108-1122, doi:10.1046/j.1365-3040.1997.d01-147.x, 1997.

Benner, T. C. and Curry, J. A.: Characteristics of small tropical cumulus clouds and their impact on the environment, J. Geophys. Res.-Atmos., 103, 28753-28767, doi:10.1029/98JD02579, 1998.

Betts, A. K. and Dias, M. A. F. S.: Progress in understanding landsurface-atmosphere coupling from LBA research, J. Adv. Model Earth Syst., 2, 20 pp., doi:10.3894/James.2010.2.6, 2010.

Collatz, G. J., Ball, J. T., Grivet, C., and Berry, J. A.: Physiological and environmental-regulation of stomatal conductance, photosynthesis and transpiration - a model that includes a laminar boundary-layer, Agr. Forest Meteorol., 54, 107-136, doi:10.1016/0168-1923(91)90002-8, 1991.

Chu, D. A., Kaufman, Y. J., Ichoku, C., Remer, L. A., Tanré, D., and Holben, B. N.: Validation of MODIS aerosol optical depth retrieval over land, Geophys. Res. Lett., 29, 8007, doi:10.1029/2001GL013205, 2002.

da Rocha, H. R., Goulden, M. L., Miller, S. D., Menton, M. C., Pinto, L. D. V. O., de Freitas, H. C., and Figueira, A. M. E. S.: Seasonality of water and heat fluxes over a tropical forest in eastern Amazonia, Ecol. Appl., 14, 22-32, 2004.

da Rocha, H. R., Manzi, A. O., Cabral, O. M., Miller, S. D., Goulden, M. L., Saleska, S. R., Coupe, N. R., Wofsy, S. C., Borma, L. S., Artaxo, P., Vourlitis, G., Nogueira, J. S., Cardoso, F. L., Nobre, A. D., Kruijt, B., Freitas, H. C., von Randow, C., Aguiar, R. G., and Maia, J. F.: Patterns of water and heat flux across a biome gradient from tropical forest to savanna in Brazil, J. Geophys. Res.-Biogeo., 114, G00B12, doi:10.1029/2007JG000640, 2009.

Davidi, A., Koren, I., and Remer, L.: Direct measurements of the effect of biomass burning over the Amazon on the atmospheric temperature profile, Atmos. Chem. Phys., 9, 8211-8221, doi:10.5194/acp-9-8211-2009, 2009.

Davidson, E. A., de Araujo, A. C., Artaxo, P., Balch, J. K., Brown, I. F., Bustamante, M. M. C., Coe, M. T., DeFries, R. S., Keller, M., Longo, M., Munger, J. W., Schroeder, W., Soares, B. S., Souza, C. M., and Wofsy, S. C.: The Amazon basin in transition, Nature, 481, 321-328, doi:10.1038/Nature10717, 2012. 
de Araujo, A. C., Dolman, A. J., Waterloo, M. J., Gash, J. H. C., Kruijt, B., Zanchi, F. B., de Lange, J. M. E., Stoevelaar, R., Manzi, A. O., Nobre, A. D., Lootens, R. N., and Backer, J.: The spatial variability of $\mathrm{CO}_{2}$ storage and the interpretation of eddy covariance fluxes in central Amazonia, Agr. Forest Meteorol., 150, 226-237, 2010

Dolman, A. J., Valentini, R., Groenendijk, M., and Hendriks, D.: Flux tower sites, state of the art, and network design, in: The Continental-Scale Greenhouse Gas Balance of Europe, edited by: Dolman, A. J., Valentini, R., and Freibauer, A., Ecological Studies, Springer, New York, 215-242, 2008.

Doughty, C. E., Flanner, M. G., and Goulden, M. L.: Effect of smoke on subcanopy shaded light, canopy temperature, and carbon dioxide uptake in an Amazon rainforest, Global Biogeochem. Cy., 24, GB3015, doi:10.1029/2009GB003670, 2010.

Duchon, C. E. and O'Malley, M. S.: Estimating cloud type from pyranometer observations, J. Appl. Meteorol., 38, 132-141, 1999.

Eck, T. F., Holben, B. N., Reid, J. S., O’Neill, N. T., Schafer, J. S., Dubovik, O., Smirnov, A., Yamasoe, M. A., and Artaxo, P.: High aerosol optical depth biomass burning events: a comparison of optical properties for different source regions, Geophys. Res. Lett., 30, 2035, doi:10.1029/2003GL017861, 2003.

Ferraz, J., Ohta, S., and Salles, P. C.: Distribuição dos solos ao longo de dois transectos em floresta primária ao norte de Manaus (AM), in: Pesquisas Florestais para Conservação da Floresta e Reabilitação de Áreas Degradadas da Amazônia, Manaus-AM, Brazil, MCT-INPA/JICAm, edited by: Higuchi, N., Campos, M. A. A., Sampaio, P. T. B., Santos, J., 111-143, 1998.

Finnigan, J.: The storage term in eddy flux calculations, Agr. Forest Meteorol., 136, 108-113, doi:10.1016/j.agrformet.2004.12.010, 2006.

Fisch, G., Marengo, J. A., and Nobre, C.: The climate of Amazonia - a review, Acta Amazonica, 28, 101-126, 1998 (in Portuguese).

Freedman, J. M., Fitzjarrald, D. R., Moore, K. E., and Sakai, R. K.: Boundary layer cloud climatology and enhanced forestatmosphere exchange, in: Preprints of 23rd Conference on Agricultural and Forest Meteorology, American Meteorology Society, Boston, Mass., 41-44, 1998.

Gates, D. M.: Biophysical Ecology, Springer, New York, 611 pp., 1980.

Gatti, L. V., Gloor, M., Miller, J. B., Doughty, C. E., Malhi, Y., Domingues, L. G., Basso, L. S., Martinewski, A., Correia, C. S. C., Borges, V. F., Freitas, S., Braz, R., Anderson, L. O., Rocha, H., Grace, J., Phillips, O. L., and Lloyd, J.: Drought sensitivity of Amazonian carbon balance revealed by atmospheric measurements, Nature, 506, 76-80, doi:10.1038/nature12957, 2014.

Gloor, M., Brienen, R. J. W., Galbraith, D., Feldpausch, T. R., Schongart, J., Guyot, J. L., Espinoza, J. C., Lloyd, J., and Phillips, O. L.: Intensification of the Amazon hydrological cycle over the last two decades, Geophys. Res. Lett., 40, 1729-1733, doi:10.1002/Grl.50377, 2013.

Goulden, M. L., Daube, B. C., Fan, S. M., Sutton, D. J., Bazzaz, A., Munger, J. W., and Wofsy, S. C.: Physiological responses of a black spruce forest to weather, J. Geophys. Res.-Atmos., 102, 28987-28996, doi:10.1029/97JD01111, 1997.

Gu, L., Fuentes, J. D., Shugart, H. H., Staebler, R. M., and Black, T. A.: Responses of net ecosystem exchanges of carbon dioxide to changes in cloudiness: results from two North American deciduous forests, J. Geophys. Res.-Atmos, 104, 31421-31434, doi:10.1029/1999JD901068, 1999.

Gu, L., Fuentes, J. D., Garstang, M., Silva, J. T. D., Heitz, R., Sigler, J., and Shugart, H. H.: Cloud modulation of surface solar irradiance at a pasture site in southern Brazil, Agr. Forest Meteorol., 106, 117-129, 2001.

Gu, L. H., Baldocchi, D. D., Wofsy, S. C., Munger, J. W., Michalsky, J. J., Urbanski, S. P., and Boden, T. A.: Response of a deciduous forest to the Mount Pinatubo eruption: enhanced photosynthesis, Science, 299, 2035-2038, doi:10.1126/science.1078366, 2003.

Guyon, P., Graham, B., Beck, J., Boucher, O., Gerasopoulos, E., Mayol-Bracero, O. L., Roberts, G. C., Artaxo, P., and Andreae, M. O.: Physical properties and concentration of aerosol particles over the Amazon tropical forest during background and biomass burning conditions, Atmos. Chem. Phys., 3, 951-967, doi:10.5194/acp-3-951-2003, 2003.

Higuchi, N., dos Santos, J., Vieira, G., Ribeiro, R. J., Sakurai, S., Ishizuka, M., Sakai, T., Tanaka, N., and Saito, S.: Análise estrutural da floresta primária da bacia do rio Cuieiras, ZF-2, ManausAM, Brasil, in: Pesquisas florestais para a conservação da floresta e reabilitação de áreas degradadas da Amazônia, edited by: Higuchi, N. A., Campos, M. A. A., Sampaio, P. T. B., and dos Santos, J., MCT-INPA/JICA, Manaus, 51-91, 1998 (in Portuguese).

Holben, B. N., Setzer, A., Eck, T. F., Pereira, A., and Slutsker, I.: Effect of dry-season biomass burning on Amazon basin aerosol concentrations and optical properties, 1992-1994, J. Geophys. Res.-Atmos., 101, 19465-19481, doi:10.1029/96jd01114, 1996.

Holben, B. N., Eck, T. F., Slutsker, I., Tanre, D., Buis, J. P., Setzer, A., Vermote, E., Reagan, J. A., Kaufman, Y. J., Nakajima, T., Lavenu, F., Jankowiak, I., and Smirnov, A.: AERONET - a federated instrument network and data archive for aerosol characterization, Remote Sens. Environ., 66, 1-16, doi:10.1016/S00344257(98)00031-5, 1998.

Houghton, R. A.: Carbon emissions and the drivers of deforestation and forest degradation in the tropics, Curr Opin Sust, 4, 597-603, doi:10.1016/j.cosust.2012.06.006, 2012.

Houghton, R. A., Gloor, M., Lloyd, J., and Potter, C.: The Regional Carbon Budget, Geophys Monogr Ser, 186, 409-428, doi:10.1029/2008gm000718, 2009.

Hutyra, L. R., Munger, J. W., Hammond-Pyle, E., Saleska, S. R., Restrepo-Coupe, N., Daube, B. C., de Camargo, P. B., and Wofsy, S. C.: Resolving systematic errors in estimates of net ecosystem exchange of $\mathrm{CO}_{2}$ and ecosystem respiration in a tropical forest biome, Agr. Forest Meteorol., 148, 1266-1279, doi:10.1016/j.agrformet.2008.03.007, 2008.

Jing, X., Huang, J., Wang, G., Higuchi, K., Bi, J., Sun, Y., Yu, H., and Wang, T.: The effects of clouds and aerosols on net ecosystem $\mathrm{CO}_{2}$ exchange over semi-arid Loess Plateau of Northwest China, Atmos. Chem. Phys., 10, 8205-8218, doi:10.5194/acp10-8205-2010, 2010.

Keeling, C. D., Chin, J. F. S., and Whorf, T. P.: Increased activity of northern vegetation inferred from atmospheric $\mathrm{CO}_{2}$ measurements, Nature, 382, 146-149, 1996.

Keller, M., Clark, D. A., Clark, D. B., Weitz, A. M., and Veldkamp, E.: If a tree falls in the forest, Science, 273, 5272, doi:10.1126/science.273.5272.201, 1996. 
King, M. D., Kaufman, Y. J., Tanre, D., and Nakajima, T.: Remote sensing of tropospheric aerosols from space: past, present, and future, B. Am. Meteorol. Soc., 80, 2229-2259, 1999.

King, M. D., Menzel, W. P., Kaufman, Y. J., Tanre, D., Gao, B. C., Platnick, S., Ackerman, S. A., Remer, L. A., Pincus, R., and Hubanks, P. A.: Cloud and aerosol properties, precipitable water, and profiles of temperature and water vapor from MODIS, IEEE Trans. Geosci. Remote, 41, 442-458, doi:10.1109/Tgrs.2002.808226, 2003.

Koren, I., Martins, J. V., Remer, L. A., and Afargan, H.: Smoke invigoration versus inhibition of clouds over the Amazon, Science, 321, 946-949, doi:10.1126/science.1159185, 2008.

Koren, I., Feingold, G., Jiang, H. L., and Altaratz, O.: Aerosol effects on the inter-cloud region of a small cumulus cloud field, Geophys. Res. Lett., 36, L14805, doi:10.1029/2009g1037424, 2009.

Law, B. E., Falge, E., Gu, L., Baldocchi, D. D., Bakwin, P., Berbigier, P., Davis, K., Dolman, A. J., Falk, M., Fuentes, J. D., Goldstein, A., Granier, A., Grelle, A., Hollinger, D., Janssens, I. A., Jarvis, P., Jensen, N. O., Katul, G., Mahli, Y., Matteucci, G., Meyers, T., Monson, R., Munger, W., Oechel, W., Olson, R., Pilegaard, K., Paw, K. T., Thorgeirsson, H., Valentini, R., Verma, S., Vesala, T., Wilson, K., and Wofsy, S.: Environmental controls over carbon dioxide and water vapor exchange of terrestrial vegetation, Agr. Forest Meteorol., 113, 97-120, doi:10.1016/S01681923(02)00104-1, 2002.

Loescher, H. W., Law, B. E., Mahrt, L., Hollinger, D. Y., Campbell, J., and Wofsy, S. C.: Uncertainties in, and interpretation of, carbon flux estimates using the eddy covariance technique, J. Geophys. Res.-Atmos., 111, D21S90, doi:10.1029/2005jd006932, 2006.

Machado, L. A. T., Laurent, H., Dessay, N., and Miranda, I.: Seasonal and diurnal variability of convection over the Amazonia: a comparison of different vegetation types and large scale forcing, Theor. Appl. Climatol., 78, 61-77, 2004.

Mahrt, L.: Computing turbulent fluxes near the surface: needed improvements, Agr. Forest Meteorol., 150, 501-509, doi:10.1016/j.agrformet.2010.01.015, 2010.

Malhi, Y.: The carbon balance of tropical forest regions, 1990-2005, Curr. Opin. Sust., 2, 237-244, doi:10.1016/j.cosust.2010.08.002, 2010.

Malhi, Y.: The productivity, metabolism and carbon cycle of tropical forest vegetation, J. Ecol., 100, 65-75, doi:10.1111/j.13652745.2011.01916.x, 2012.

Martin, S. T., Andreae, M. O., Artaxo, P., Baumgardner, D., Chen, Q., Goldstein, A. H., Guenther, A., Heald, C. L., Mayol-Bracero, O. L., McMurry, P. H., Pauliquevis, T., Poschl, U., Prather, K. A., Roberts, G. C., Saleska, S. R., Dias, M. A. S., Spracklen, D. V., Swietlicki, E., and Trebs, I.: Sources and properties of Amazonian aerosol particles, Rev. Geophys., 48, RG2002, doi:10.1029/2008RG000280, 2010a.

Martin, S. T., Andreae, M. O., Althausen, D., Artaxo, P., Baars, H., Borrmann, S., Chen, Q., Farmer, D. K., Guenther, A., Gunthe, S. S., Jimenez, J. L., Karl, T., Longo, K., Manzi, A., Müller, T., Pauliquevis, T., Petters, M. D., Prenni, A. J., Pöschl, U., Rizzo, L. V., Schneider, J., Smith, J. N., Swietlicki, E., Tota, J., Wang, J., Wiedensohler, A., and Zorn, S. R.: An overview of the Amazonian Aerosol Characterization Experiment 2008 (AMAZE-
08), Atmos. Chem. Phys., 10, 11415-11438, doi:10.5194/acp10-11415-2010, 2010b.

Mercado, L. M., Bellouin, N., Sitch, S., Boucher, O., Huntingford, C., Wild, M., and Cox, P. M.: Impact of changes in diffuse radiation on the global land carbon sink, Nature, 458, 1014-1087, doi:10.1038/Nature07949, 2009.

Miller, S. D., Goulden, M. L., Menton, M. C., da Rocha, H. R., de Freitas, H. C., Figueira, A. M. E. S., and de Sousa, C. A. D.: Biometric and micrometeorological measurements of tropical forest carbon balance, Ecol. Appl., 14, 114-126, 2004.

Min, Q.: Impacts of aerosols and clouds on forest-atmosphere carbon exchange, J. Geophys. Res.-Atmos., 35, L02406, doi:10.1029/2007GL032398, 2005.

Min, Q. and Wang, S.: Clouds modulate terrestrial carbon uptake in a midlatitude hardwood forest, Geophys. Res. Lett., 35, L02406, doi:10.1029/2007GL032398, 2008.

Moncrieff, J. B., Massheder, J. M., De Bruin, H., Elbers, J., Friborg, T., Heusinkveld, B., Kabat, P., Scott, S., Soegaard, H., and Verhoef, A.: A system to measure surface fluxes of momentum, sensible heat, water vapour and carbon dioxide, J. Hydrol., 188189, 589-611, 1997.

Monteith, J. L. and Unsworth, M. H.: Principles of Environmental Physics, Edward Arnold, London, UK, 1990.

Myneni, R. B., Keeling, C. D., Tucker, C. J., Asrar, G., and Nemani, R. R.: Increased plant growth in the northern high latitudes from 1981 to 1991, Nature, 386, 698-702, doi:10.1038/386698a0, 1997.

Niyogi, D., Chang,H.-I., Saxena, V. K., Holt, T., Alapaty, K., Booker, F., Chen, F., Davis, K. J., Holben, B., Matsui, T., Meyers, T., Oechel, W. C., Pielke Sr., R. A., Wells, R., Wilson, K., and Xue, Y.: Direct observations of the effects of aerosol loading on net ecosystem $\mathrm{CO}_{2}$ exchanges over different landscapes, Geophys. Res. Lett., 31, L20506, doi:10.1029/2004GL020915, 2004.

Oliveira, A. N. D. and Amaral, I. L. D.: Floristic, phytosociological and ecological aspects of terra firme understory in central Amazonia, Amazonas state, Brazil, Acta Amazonica, 35, 1-16, 2005 (in Portuguese).

Oliveira, P. H. F., Artaxo, P., Pires, C., De Lucca, S., Procópio, A., Holben, B., Schafer, J., Cardoso, L. F., Wofsy, S. C., and Rocha, H. R.: The effects of biomass burning aerosols and clouds on the $\mathrm{CO}_{2}$ flux in Amazonia, Tellus B, 59, 338-349, doi:10.1111/j.1600-0889.2007.00270.x, 2007.

Ometto, J. P., Nobre, A. D., Rocha, H. R., Artaxo, P., and Martinelli, L. A.: Amazonia and the modern carbon cycle: lessons learned, Oecologia, 143, 483-500, doi:10.1007/s00442005-0034-3, 2005.

Phillips, O. L., Malhi, Y., Higuchi, N., Laurance, W. F., Núñez, P. V., Vásquez, R. M., Laurance, S. G., Ferreira, L. V., Stern, M., Brown, S., and Grace, J.: Changes in the carbon balance of tropical forests: evidence from long-term plots, Science, 282, 439442, doi:10.1126/science.282.5388.439, 1998.

Procopio, A. S., Artaxo, P., Kaufman, Y. J., Remer, L. A., Schafer, J. S., and Holben, B. N.: Multiyear analysis of amazonian biomass burning smoke radiative forcing of climate, Geophys. Res. Lett., 31, L03108, doi:10.1029/2003GL018646, 2004.

Reindl, D. T., Beckman, W. A., and Duffie, J. A.: Diffuse fraction correlations, Sol. Energy, 45, 1-7, doi:10.1016/0038092x(90)90060-P, 1990. 
Remer, L. A., Kaufman, Y. J., Tanre, D., Mattoo, S., Chu, D. A., Martins, J. V., Li, R. R., Ichoku, C., Levy, R. C., Kleidman, R. G., Eck, T. F., Vermote, E., and Holben, B. N.: The MODIS aerosol algorithm, products, and validation, J. Atmos. Sci., 62, 947-973, doi:10.1175/Jas3385.1, 2005.

Remer, L. A., Mattoo, S., Levy, R. C., and Munchak, L. A.: MODIS $3 \mathrm{~km}$ aerosol product: algorithm and global perspective, Atmos. Meas. Tech., 6, 1829-1844, doi:10.5194/amt-6-1829-2013, 2013.

Rennó, C. D., Nobre, A. D., Cuartas, L. A., Soares, J. V., Hodnett, M. G., Tomasella, J., and Waterloo, M. J.: HAND, a new terrain descriptor using SRTM-DEM: mapping terra-firme rainforest environments in Amazonia, Remote Sens. Environ., 112, 3469-3481, 2008.

Ricchiazzi, P., Yang, S., Gautier, C., and Sowle, D.: SBDART: a research and teaching software tool for plane-parallel radiative transfer in the Earth's atmosphere, B. Am. Meteorol. Soc., 79, 2101-2114, 1998.

Richardson, A. D. and Hollinger, D. Y.: Statistical modeling of ecosystem respiration using eddy covariance data: Maximum likelihood parameter estimation, and Monte Carlo simulation of model and parameter uncertainty, applied to three simple models, Agr. Forest Meteorol., 131, 191-208, doi:10.1016/j.agrformet.2005.05.008, 2005.

Schafer, J. S., Eck, T. F., Holben, B. N., Artaxo, P., Yamasoe, M. A., and Procopio, A. S.: Observed reductions of total solar irradiance by biomass-burning aerosols in the Brazilian Amazon and Zambian Savanna, Geophys. Res. Lett., 29, 1823, doi:10.1029/2001GL014309, 2002.

Seinfeld, J. H. and Pandis, S. N.: Atmospheric Chemistry and Physics - from Air Pollution to Climate Change, 2nd edn., John Wiley \& Sons, USA, 2006.

Sena, E. T., Artaxo, P., and Correia, A. L.: Spatial variability of the direct radiative forcing of biomass burning aerosols and the effects of land use change in Amazonia, Atmos. Chem. Phys., 13, 1261-1275, doi:10.5194/acp-13-1261-2013, 2013.
Silva Dias, M. A. F., Rutledge, S., Kabat, P., Silva Dias, P. L., Nobre, C., Fisch, G., Dolman, A. J., Zipser, E., Garstang, M., Manzi, A. O., Fuentes, J. D., Rocha, H. R., Marengo, J., Plana-Fattori, A., Sá, L. D. A., Alvalá, R. C. S., Andreae, M. O., Artaxo, P., Gielow, R., and Gatti, L.: Cloud and rain processes in a biosphereatmosphere interaction context in the Amazon Region, J. Geophys. Res.-Atmos., 107, 8072, doi:10.1029/2001jd000335, 2002.

Spitters, C. J. T.: Separating the diffuse and direct component of global radiation and its implications for modeling canopy photosynthesis - 2. Calculation of canopy photosynthesis, Agr. Forest Meteorol., 38, 231-242, doi:10.1016/0168-1923(86)90061-4, 1986.

Tóta, J., Fitzjarrald, D. R., Staebler, R. M., Sakai, R. K., Moraes, O. M. M., Acevedo, O. C., Wofsy, S. C., and Manzi, A. O.: Amazon rain forest subcanopy flow and the carbon budget: Santarém LBA-ECO site, J. Geophys. Res., 113, G00B02, doi:10.1029/2007jg000597, 2008.

von Randow, C., Manzi, A. O., Kruijt, B., de Oliveira, P. J., Zanchi, F. B., Silva, R. L., Hodnett, M. G., Gash, J. H. C., Elbers, J. A., Waterloo, M. J., Cardoso, F. L., and Kabat, P.: Comparative measurements and seasonal variations in energy and carbon exchange over forest and pasture in South West Amazonia, Theor. Appl. Climatol., 78, 5-26, doi:10.1007/s00704-004-0041-z, 2004.

Vourlitis, G. L., de Almeida Lobo, F., Zeilhofer, P., and de Souza Nogueira, J.: Temporal patterns of net $\mathrm{CO}_{2}$ exchange for a tropical semideciduous forest of the southern Amazon Basin, J. Geophys. Res., 116, G03029, doi:10.1029/2010JG001524, 2011.

Yamasoe, M. A., von Randow, C., Manzi, A. O., Schafer, J. S., Eck, T. F., and Holben, B. N.: Effect of smoke and clouds on the transmissivity of photosynthetically active radiation inside the canopy, Atmos. Chem. Phys., 6, 1645-1656, doi:10.5194/acp-61645-2006, 2006.

Zhang, M., Yu, G.-R., Zhang, L.-M., Sun, X.-M., Wen, X.-F., Han, S.-J., and Yan, J.-H.: Impact of cloudiness on net ecosystem exchange of carbon dioxide in different types of forest ecosystems in China, Biogeosciences, 7, 711-722, doi:10.5194/bg-7711-2010, 2010. 